\title{
Shelf-to-basin iron shuttle in the Guaymas Basin, Gulf of California
}

Florian Scholz*, Mark Schmidt, Christian Hensen, Sümeyya Eroglu, Sonja Geilert, Marcus Gutjahr, Volker Liebetrau

GEOMAR Helmholtz Centre for Ocean Research Kiel, Wischhofstrasse 1-3, 24148 Kiel, Germany Corresponding author: E-mail: fscholz@geomar.de, phone: +49 (0)431 6002113

\section{Abstract}

Enrichments of highly reactive iron (Fe) (sum of Fe (oxyhydr)oxide, carbonate and sulfide minerals) in marine sediments and sedimentary rocks are commonly interpreted as an indication of anoxic conditions in the bottom water at the time of deposition. The model system for this proxy rationale is the semi-restricted Black Sea, where sediments underneath the anoxic and sulfidic (i.e., euxinic) deep-water are enriched in reactive Fe, which was mobilized from the surrounding shelf areas. To test whether such a shelf-to-basin Fe shuttle can operate in semi-restricted basins without euxinic deep water, we investigated sedimentary Fe speciation and Fe isotope compositions in sediments of the Guaymas Basin, Gulf of California. Sediments on the slope underneath the eastern equatorial Pacific oxygen minimum zone and sediments within the oxic deep basin are both enriched in reactive $\mathrm{Fe}$, with reactive Fe making up $45 \pm 11 \%$ of the total Fe pool. The following mechanisms may contribute to these Fe enrichments: (1) Release of dissolved Fe from anoxic shelf and slope sediments followed by lateral transport of dissolved and/or particulate Fe in the water column; (2) preferential transport of fine-grained, terrigenous particles with a high reactive Fe content into the basin; (3) microbially mediated conversion of non-reactive silicate minerals to reactive Fe minerals during transport; (4) hydrothermal venting and lateral Fe transport within the deep water. The first process can explain reactive $\mathrm{Fe}$ enrichments in slope sediments, whereas all processes may contribute to sedimentary Fe enrichments in the deeper basin.

The $\delta^{56} \mathrm{Fe}$ value of sediments increases from shelf to slope and decreases from the slope into the basin. This lateral pattern of $\delta^{56} \mathrm{Fe}$, as well as the pattern of Fe enrichment, is similar to that observed in other marine systems with a Fe shuttle. However, the size of the Fe enrichment, and the range in $\delta^{56} \mathrm{Fe}(-0.06$ to $+0.16 \%)$ is smaller. This difference is due to higher terrigenous sedimentation rates in the Guaymas Basin and, therefore, more intense dilution of shuttle-derived reactive Fe. We argue that, depending on the extent of bathymetric restriction and terrigenous background sedimentation, reactive Fe enrichments can form under a broad range of redox conditions and in diverse 
sedimentary environments. The concepts applied in this study can be used to identify those circumstances in the paleo-record.

Key words: reactive iron, iron shuttle, paleo-redox, oxygen minimum zone, hydrothermal vent.

\section{Introduction}

Iron ( $\mathrm{Fe})$ is an essential micronutrient in the ocean, and can limit nitrogen fixation and primary production (Falkowski et al., 1997; Moore and Doney, 2007; Boyd and Ellwood, 2010). While atmospheric dust has long been considered the main source of bioavailable Fe to the ocean (Jickells et al., 2005), recent work has highlighted the importance of continental margin sediments and hydrothermal vents as sources of Fe to marine phytoplankton (Moore and Braucher, 2008; Tagliabue et al., 2010; Dale et al., 2015; Tagliabue et al., 2017). In ocean regions with Fe-limited primary production (e.g., high-nutrient-low-chlorophyll (HNLC) regions), external Fe supply plays a critical role for the extent to which carbon dioxide can be removed from the upper ocean and atmosphere via export production. Therefore, paleoclimatologists and paleoceanographers have a keen interest in understanding how Fe transfer from source to sink areas is recorded in sedimentary archives (e.g., Murray et al., 2012; Martínez-García et al., 2014; Scholz et al., 2014a).

The solubility of $\mathrm{Fe}$ in seawater and sediment pore waters reaches a maximum under anoxic (zero oxygen) to weakly sulfidic (below saturation of Fe monosulfide minerals, FeS) conditions. Therefore, Fe can be released from anoxic sediments (Elrod et al., 2004; Severmann et al., 2010, Noffke et al., 2012) and then be transported within the water column, either as dissolved ferrous Fe (Fe(II)) under low-oxygen conditions, or as organically complexed, colloidal or nanoparticulate ferric $\mathrm{Fe}(\mathrm{Fe}(\mathrm{III}))$ under oxic conditions (Lohan and Bruland, 2008; Boyd and Ellwood, 2010; Noble et al., 2012; Kondo and Moffett, 2015). If dissolved, colloidal or nanoparticulate Fe is subsequently transferred into an ocean region with a lower capacity for Fe transport, e.g., because of oxic or strongly sulfidic conditions, authigenic Fe minerals ((oxyhydr)oxides, sulfides, carbonates) are precipitated and deposited at the seafloor. Under such conditions, the accumulation of highly reactive $\mathrm{Fe}\left(\mathrm{Fe}_{\mathrm{HR}}\right.$, defined as the sum of Fe bound to (oxyhydr)oxides, carbonates and sulfide minerals) can be decoupled from the terrigenous $\mathrm{Fe}$ input, thus leading to elevated ratios of $\mathrm{Fe}_{\mathrm{HR}}$ to total $\mathrm{Fe}\left(\mathrm{Fe}_{\mathrm{T}}\right)$ and $\mathrm{Fe}_{\mathrm{T}}$ to $\mathrm{Al}$ compared to terrigenous particles or sediments that are unaffected by additional Fe input (Lyons and Severmann, 2006; Poulton and Canfield, 2011; Raiswell and Canfield, 2012). The prototypical location of this so-called "benthic Fe shuttle" is the anoxic-sulfidic (i.e., euxinic) Black Sea, where shelf-derived Fe accumulates in sediments of the deep basin as pyrite $\left(\mathrm{FeS}_{2}\right)$ (Anderson and Raiswell, 2004; Raiswell and Anderson, 2005; Lyons and Severmann, 2006). Using the euxinic Black Sea as a paradigm, elevated $\mathrm{Fe}_{\mathrm{HR}} / \mathrm{Fe}_{\mathrm{T}}$ and $\mathrm{Fe}_{\mathrm{T}} / \mathrm{Al}$ in combination with a high extent of 
pyritization of the reactive $\mathrm{Fe}$ pool $\left(\mathrm{Fe}_{\mathrm{py}} / \mathrm{Fe}_{\mathrm{HR}}\right)$ are widely used as proxies for anoxic and sulfidic conditions in the water column of paleo-marine systems (Raiswell and Canfield, 2012). In an analogous manner, elevated $\mathrm{Fe}_{\mathrm{HR}} / \mathrm{Fe}_{\mathrm{T}}$ in combination with a low $\mathrm{Fe}_{\mathrm{py}} / \mathrm{Fe}_{\mathrm{HR}}$ is interpreted as an indicator for anoxic but non-euxinic, so-called ferruginous conditions. This redox state, where dissolved ferrous Fe dominates over oxygen, nitrate and hydrogen sulfide $\left(\mathrm{H}_{2} \mathrm{~S}\right)$, does not exist in the modern ocean but may have been dominant through much of Earth's history (Poulton and Canfield, 2011).

Since the Black Sea was established as a paradigm for the benthic or "shelf-to-basin" Fe shuttle, a number of studies have demonstrated that Fe transfer from source to sink areas is a common feature in the ocean and not necessarily restricted to environments where $\mathrm{H}_{2} \mathrm{~S}$ or dissolved ferrous Fe are the dominant redox species. For example, in the oxygen minimum zones (OMZ) of upwelling regions, sedimentary Fe release is particularly intense (Elrod et al., 2004; Severmann et al., 2010; Noffke et al., 2012, Dale et al., 2015) and sediments at the boundaries of OMZs tend to be enriched in reactive Fe relative to terrigenous material (Scholz et al., 2014b; Scholz, 2018). Furthermore, water column studies, mostly conducted within the GEOTRACES program, demonstrated far-field transport of Fe from sedimentary and hydrothermal sources (Noble et al., 2012; Conway and John, 2014; Resing et al., 2015; John et al., 2018). Whether or not Fe shuttling results in a sedimentary fingerprint at a given location critically depends on the local balance between non-lithogenic (i.e., shuttle-derived) and lithogenic (i.e., terrigenous) Fe flux (Lyons and Severmann, 2006; Scholz, 2018). For example, in the semi-enclosed Black Sea, shelf-derived Fe is inevitably channeled into the basin, where detrital sedimentation rates are low. This combination of basin geometry and low terrigenous Fe and $\mathrm{Al}$ supply is highly favorable for generating elevated $\mathrm{Fe}_{\mathrm{HR}} / \mathrm{Fe}_{\mathrm{T}}$ and $\mathrm{Fe}_{\mathrm{T}} / \mathrm{Al}$ (Scholz, 2018). In principle, however, sedimentary Fe enrichments are virtually unrelated to the redox state of the deep-water in the Fe sink area. Even if the deep-water was oxic, shelf-derived Fe could not escape burial in the basin. One could therefore hypothesize that reactive Fe enrichments are not necessarily indicative of euxinic (or ferruginous) anoxia, but rather related to enhanced Fe supply from non-lithogenic sources, which can be achieved under a broad range of redox conditions in the sink area.

Our study area, the Guaymas Basin in the Gulf of California (Fig. 1A), is an ideal system to test this hypothesis. Similar to the Black Sea, the Guaymas Basin has a semi-restricted bathymetry and the deep-water is separated from neighboring basins and the open ocean by a sill. At intermediate depth, the Eastern Equatorial Pacific OMZ impinges the seafloor, which is expected to result in sedimentary Fe release. Moreover, the Guaymas Basin is an early rifting environment (Curray and Moore, 1982), where circulation of hydrothermal fluids through young oceanic crust and overlying hemi-pelagic sediments can mobilize Fe into the oxic deep-water. In a previous study, Campbell et al. 
(1988) found that the basin sediments are strongly enriched in manganese $(\mathrm{Mn})$ relative to terrigenous material deriving from both hydrothermal and sedimentary sources. Overall, the Guaymas Basin shares many characteristics with predominantly oxic ocean basins like the Pacific but is relatively small and semi-restricted like the euxinic Black Sea. In the present article, we address the following questions: Are sediments in the Guaymas Basin characterized by variability in $\mathrm{Fe}_{\mathrm{T}} / \mathrm{Al}$ and $\mathrm{Fe}_{\mathrm{HR}} / \mathrm{Fe}_{\mathrm{T}}$, which can be attributed to a shelf-to-basin $\mathrm{Fe}$ shuttle or hydrothermal Fe input? Is it possible to distinguish these two non-lithogenic sources of reactive Fe by the aid of Fe speciation and sedimentary Fe isotopes? Our ultimate goal is to better understand how basin-scale Fe transport is recorded in sedimentary paleo-archives.

\section{Study area and samples}

The Gulf of California (Fig. 1A) is located between the Mexican mainland and the Baja California peninsula. Circulation and primary productivity in this area are modulated by the atmospheric Monsoon circulation over southwestern North America (Thunell, 1998). During the winter season, a high pressure system overlying the southwestern USA forces northeasterly winds, which transport surface waters in the Gulf of California in a southward direction. The southward emplacement of surface water drives upwelling of nutrient-rich subsurface water and high rates of primary and export production (Marinone, 2003). By contrast, during summer season, the region north of the Gulf of California is characterized by low atmospheric pressure. Consequently, the direction of winds and surface currents reverse, which leads to a cessation of upwelling and low rates of primary production (Thunell, 1998; Marinone, 2003). Below the seasonally varying surface water masses is the oxygendepleted North Pacific intermediate water between 500 and 1000 m water depth (Bray, 1988). Analogous to the Eastern Equatorial Pacific outside the Gulf of California, oxygen concentrations increase again below the OMZ. During the productive winter season, sedimentation in the Gulf of California is dominated by biogenous material (diatomaceous ooze), whereas in the rainy summer season terrigenous material is supplied by river runoff and intermittent dust storms (Thunell et al., 1993). The lack of bioturbation within sediments underneath the OMZ leads to the formation of laminated sediments, which reflect the seasonally changing climatic and oceanographic conditions in the Gulf of California (Calvert et al., 1966).

The Guaymas Basin in the central Gulf of California is an early rifting environment with spreading rates of about $6 \mathrm{~cm} \mathrm{yr}^{-1}$ between the Pacific and North American plates (Curray and Moore, 1982). Its spreading axis consists of two graben systems, the northern and southern trough, separated by a strike-slip fault. In the early 1980s, hydrothermal vents were discovered in the southern trough (close to DSDP Site 477) (Fig. 1) (Von Damm et al., 1985). Due to high sedimentation rates within the basin (up to $2.8 \mathrm{~m} \mathrm{kyr}^{-1}$ ) (Calvert et al., 1966), hydrothermal fluids percolate through newly formed oceanic 
crust and several hundred meters of organic matter-rich hemipelagic sediments (Simoneit et al., 1988). Due to interactions of hydrothermal fluids with and precipitation of metal sulfides within the sediments overlying the intrusion zone, emanating hydrothermal fluids are relatively poor in oreforming metals compared to bare ridge crest hydrothermal systems (e.g., tens of $\mu \mathrm{M}$ of Fe instead of hundreds to thousands of $\mu \mathrm{M}$ at the East Pacific Rise) (Von Damm et al., 1995). During RV Sonne cruise SO241 in June and July 2015, a new hydrothermal vent area was discovered next to the northern trough (Bernd et al., 2016; Geilert et al., 2018). The hydrothermal fluids discharged in this northern vent field are similar to those sampled earlier at the southern trough.

The samples presented in this article (Table 1) were collected during RV Sonne cruise SO241 along two transects across the eastern shelf and slope of the Guaymas basin (Fig. 1B) and across the basin, northern trough and hydrothermal vent field (Fig. 1C). The 'shelf site' is located in a shallow embayment off the coast of the Mexican mainland. Sediments at this site are sandy, presumably reflecting strong bottom currents causing winnowing of fine-grained material. Due to the anoxic bottom water, sediments at the 'OMZ site' are laminated. The water depth and environmental setting at this station are similar to DSDP Site 480. Another core with low bottom water oxygen concentrations was taken at the lower rim of the OMZ ('OMZ rim site'). This site is located well above the depth of the sill ( 1500 m water depth) (Fig 1A), which separates the Guaymas basin from the neighboring Carmen Basin. The 'basin site' and 'graben site' are located within the western basin plain and northern trough, respectively. Sediments in these areas are bioturbated and bottom water oxygen concentrations range from 35 to $40 \mu \mathrm{M}$. The 'vent field site' is located within the newly discovered vent field east of the northern trough (Bernd et al., 2016; Geilert et al., 2018). Sediments in this area consist of debris of collapsed vent edifices covered by a thin layer of hemipelagic sediments.

\section{Methods}

\subsection{Shipboard sampling and operation}

The water column was sampled using a video-guided rosette of $11 \times 10$ I Niskin bottles equipped with a Seabird 9plus CTD and additional sensors measuring, among others, oxygen and turbidity (Linke et al., 2015). Water samples were collected from the Niskin bottles for on-board analyses of oxygen, nitrate $\left(\mathrm{NO}_{3}{ }^{-}\right)$, nitrite $\left(\mathrm{NO}_{2}{ }^{-}\right)$and phosphate $\left(\mathrm{PO}_{4}{ }^{3-}\right)$. About 5 I of water were used to collect particles on acid-cleaned polyether sulfone filters $(0.2 \mu \mathrm{M}, 47 \mathrm{~mm}$ diameter) (PALL corporation) by offline filtration. The filtration units were acid-cleaned prior to each use. To determine current directions and velocities in the Guaymas Basin above the hydrothermal vent field, a lander-mounted upwardlooking 300 kHz ADCP (Teledyne RDI, Workhorse Sentinel Acoustic Doppler Current Profiler) was 
deployed about $500 \mathrm{~m}$ southeast of the vent field site. The ADCP lander recorded data for the lowermost $\sim 100 \mathrm{~m}$ of the water column at $2 \mathrm{~m}$ resolution over a time period of about 40 hours.

Short sediment cores with supernatant bottom water were retrieved using a video-guided multiple corer (MUC). Upon recovery on deck, sediment cores were transferred to a cool lab, where the temperature was adjusted to seafloor conditions. The bottom water was siphoned off with a syringe attached to a Tygon tube and stored for later analyses along with pore water samples. Sediment subsampling was done in an argon-flushed glove bag as described in Scholz et al. (2011). The pore water was separated from the solid phase by centrifuging for 20 minutes at $4000 \mathrm{rpm}$. Centrifuge vials were then transferred to a second glove bag and the supernatant water was filtered through cellulose acetate syringe filters. One $\mathrm{ml}$ of pore water was mixed with ascorbic acid in the glove bag for on-board analysis of dissolved ferrous $\mathrm{Fe}\left(\mathrm{Fe}^{2+}\right)$. Subsamples for dissolved metal analyses were stored in acid-cleaned LDPE vials and acidified with concentrated $\mathrm{HNO}_{3}$ (supra pure). A sediment subsample was stored in air-tight plastic containers for the determination of water content and porosity as well as for solid phase analyses after the cruise.

\subsection{Chemical and isotopic analyses}

A Winkler titration was applied on-board to determine oxygen concentrations in the water column. Concentrations of $\mathrm{NO}_{3}{ }^{-}, \mathrm{NO}_{2}{ }^{-}$, ammonia $\left(\mathrm{NH}_{4}{ }^{+}\right), \mathrm{PO}_{4}{ }^{3-}, \mathrm{Fe}^{2+}$ and $\mathrm{H}_{2} \mathrm{~S}\left(\sum \mathrm{H}_{2} \mathrm{~S}=\mathrm{H}_{2} \mathrm{~S}+\mathrm{HS}^{-}+\mathrm{S}_{2}{ }^{-}\right)$in water column and/or pore water samples were analyzed on-board by standard spectrophotometric techniques (Stooky, 1970; Grasshoff et al., 2002). Dissolved Mn concentrations were determined at GEOMAR by inductively coupled plasma optical emission spectroscopy (ICP-OES, VARIAN 720-ES).

Total organic carbon (TOC) was analyzed using an element analyzer (Euro EA, HEKAtech) after removal of inorganic carbon with $1 \mathrm{M} \mathrm{HCl}$. To determine particulate $\mathrm{Fe}, \mathrm{Mn}$, aluminum (Al) and titanium (Ti) concentrations in the solid phase, water column particulate matter collected on filters and sediment samples were digested on a hotplate and the resulting solutions were analyzed by ICPOES. Water column particulate matter was digested in an acid mix consisting of $1 \mathrm{ml}$ concentrated $\mathrm{HNO}_{3}$ (sub-boiled distilled), 0.4 M HF (Suprapur) and $0.6 \mathrm{ml}$ deionized water as described in Cutter et al. (2017). Sediment samples were digested in $\mathrm{HNO}_{3}$ (sub-boiled distilled), $\mathrm{HF}$ (Suprapur) and $\mathrm{HClO}_{4}$ (analytical grade). For quality control, Certified Reference Materials SDO-1 (Devonian Ohio Shale, USGS) and MESS-3 (marine sediment, Canadian Research Council) were digested and analyzed along with sediment samples. Since there is no Certified Reference Material for water column particulate matter, we evaluated the accuracy and precision of our procedure by digesting an in-house standard from Oregon State University (MT5-NS-1750M), which consists of particulate matter collected in a 
sediment trap in the eastern North Pacific. Recommended and measured concentrations are reported in Table 2.

A sequential extraction scheme was applied to determine operationally defined pools of reactive $\mathrm{Fe}$ minerals in sediment samples (Poulton and Canfield, 2005). In brief, Fe bound to carbonate minerals $\left(\mathrm{Fe}_{\mathrm{carb}}\right)$ was extracted with sodium acetate, $\mathrm{Fe}$ bound to (oxyhydr) oxide minerals $\left(\mathrm{Fe}_{\mathrm{ox}}\right)$ was extracted with hydroxylamine- $\mathrm{HCl}\left(\mathrm{Fe}_{\mathrm{Ox} 1}\right)$ and sodium dithionite $\left(\mathrm{Fe}_{\mathrm{Ox} 2}\right)$ and magnetite $\mathrm{Fe}\left(\mathrm{Fe}_{\mathrm{Mag}}\right)$ was extracted with ammonium oxalate. Extraction solutions were analyzed for Fe concentration by ICP-OES with yttrium as an internal standard. Concentrations of $\mathrm{Fe}$ bound to pyrite $\left(\mathrm{Fe}_{\mathrm{py}}\right)$ were determined by the chromium reduction method (Canfield et al., 1986). The sum of these four fractions represents the highly reactive Fe pool $\left(\mathrm{Fe}_{\mathrm{HR}}\right)$ which can be compared to the total Fe concentration $\left(\mathrm{Fe}_{\mathrm{T}}\right)$ obtained by total digestion. Our in-house standard OMZ-1 (Peru margin sediment) and the Certified Reference Material PACS-3 (marine sediment, Canadian Research Council) were extracted during each batch of sequential extractions. The results for the sum of highly reactive Fe without Fe bound to pyrite $\left(\mathrm{Fe}_{\mathrm{py}}\right)$ were consistent with data generated at the University of Southern Denmark (SDU) for the same standard material (GEOMAR, OMZ-1: $0.47 \pm 0.02$ wt. \%, $n=18$, PACS-3: $1.25 \pm 0.01$ wt. $\%, n=7$; SDU, OMZ-1: $0.44 \pm 0.05$ wt. \%, $n=3$, PACS-3: $1.26 \pm 0.04$ wt.\%, $n=12)$. The accuracy of the Fe $e_{p y}$ method was evaluated by determining the pyrite content of mixtures of pure pyrite and quartz sand, and $\mathrm{Fe}_{\mathrm{py}}$ was typically within $5 \%$ of target values.

For Fe isotope analyses, digestion solutions were purified following the method described in Schoenberg and von Blanckenburg (2005) using anion exchange columns containing $1 \mathrm{ml}$ BioRad $A G^{\circledR} 1-X 8$ 200-400 mesh resin. After pre-cleaning with diluted $\mathrm{HNO}_{3}, \mathrm{HCl}$ and $\mathrm{H}_{2} \mathrm{O}$, the resin was conditioned with $5 \mathrm{ml}$ of $6 \mathrm{M} \mathrm{HCl}$. About $50 \mathrm{mg}$ of $\mathrm{Fe}$ in $6 \mathrm{M} \mathrm{HCl}$ was loaded onto the resin and stepwise washed with a total of $6 \mathrm{ml} 6 \mathrm{M} \mathrm{HCl}$ to elute matrix elements. Iron was eluted with $2 \mathrm{ml}$ of $\mathrm{H}_{2} \mathrm{O}$ and $4 \mathrm{ml}$ of $5 \mathrm{M} \mathrm{HNO}_{3}$. The Fe eluate was then dried down and re-dissolved in $2 \% \mathrm{HNO}_{3}$ for isotope measurements. Iron isotope measurements were performed on a Thermo Scientific Neptune Plus multicollector-inductively coupled plasma-mass spectrometer (MC-ICP-MS) at GEOMAR using the standard-sample-bracketing method (Schoenberg and von Blanckenburg, 2005). Solutions of samples and standards were measured in high-resolution mode $(M / \Delta M>9000)$ in 20 cycles over three minutes at a concentration of $4.5 \mu \mathrm{g} \mathrm{g}^{-1}$ and at a signal of approximately $13 \mathrm{~V}$ on ${ }^{56} \mathrm{Fe}$. Signal intensities of masses ${ }^{53} \mathrm{Cr},{ }^{54} \mathrm{Fe},{ }^{56} \mathrm{Fe},{ }^{57} \mathrm{Fe},{ }^{58} \mathrm{Fe}$ as well as ${ }^{60} \mathrm{Ni}$ were acquired in static mode. Isobaric correction accounting for trace abundances of $\mathrm{Cr}$ and $\mathrm{Ni}$ in sample solutions were applied during data reduction. Iron isotope data are reported in per mil delta notation relative to the reference standard IRMM-014 $\left(\delta^{56} \mathrm{Fe}=\left({ }^{56} \mathrm{Fe} /{ }^{54} \mathrm{Fe}\right)_{\text {sample }} /\left({ }^{56} \mathrm{Fe} /{ }^{54} \mathrm{Fe}\right)_{\text {standard }}-1 \times 10^{3}\right)$. Procedural blanks were generally less than $0.5 \%$ of the total amount of Fe that passed through the Fe purification procedure and is, thus, 
negligible for the samples' Fe isotope compositions. The external reproducibility was determined by repeated analyses of the BHVO-1 standard (Basalt, Hawaiian Volcanic Observatory, USGS), which gave $\delta^{56} \mathrm{Fe}=+0.11 \pm 0.06 \%$ o $(2 \mathrm{SD}, \mathrm{n}=23)$. This values is in agreement with an average of $+0.11 \pm$ $0.01 \%$ reported by Craddock and Dauphas (2010). Repeated analyses of the SDO-1 standard (Devonian Ohio Shale, USGS) gave a $\delta^{56} \mathrm{Fe}$ of $+0.02 \pm 0.02 \%$ ( $2 \mathrm{SD}, \mathrm{n}=7$ ), which is in agreement with an average of $-0.05 \pm 0.14 \%$ reported by Severmann et al. (2010). The long-term external reproducibility of BHVO-1 $(0.06 \%)$ is used to illustrate analytical uncertainty in the figures.

\section{Results}

\subsection{Water column}

Oxygen concentrations decrease from close to saturation at the surface to values below the detection limit ( $2 \mu \mathrm{M}$ ) at 550 to $750 \mathrm{~m}$ water depth (Fig. 2). Water masses in the shallow subsurface and within the $\mathrm{OMZ}$ are characterized by a nitrate deficit relative to phosphate $\left(\mathrm{N}^{*}=\mathrm{NO}_{3}^{-}-16 \times \mathrm{PO}_{4}{ }^{-}\right.$ ) compared to the average nitrogen to phosphorus ratio of phytoplankton (so-called Redfield ratio). The nitrate deficit (negative $\mathrm{N}^{*}$ ) indicates that these water masses are affected by denitrification (Gruber and Sarmiento, 1997). Below the OMZ, oxygen concentrations increase to values of the order of 35 to $40 \mu \mathrm{M}$ in the deep-water. Turbidity is elevated within the productive surface ocean and increases progressively with depth below the water mass boundary between North Pacific Intermediate Water and Pacific Deep-water (Bray et al., 1988). A further increase in turbidity is observed below the depth of the sill and within the deep-water of the northern trough. Our water column observations (Fig. 2) are generally consistent with previous studies in the Gulf of California (Campbell and Gieskes, 1984; White et al., 2013).

Particulate $\mathrm{Mn}(\mathrm{pMn})$ and Fe $(\mathrm{pFe})$ data are presented as concentrations per volume of seawater and as $\mathrm{pFe}$ and $\mathrm{pMn}$ to particulate $\mathrm{Al}$ (pAl) ratios (Fig. 2). By normalizing $\mathrm{pFe}$ and $\mathrm{pMn}$ to $\mathrm{pAl}$, we can differentiate particles of terrigenous origin (ratio equals upper continental crust, UCC) (McLennan, 2001) from particles that contain excess Fe or Mn due to oxidation and precipitation of sediment-or hydrothermal-derived Fe and $\mathrm{Mn}$ in the water column. Since filtration was realized offline, oxidation and precipitation of dissolved $\mathrm{Fe}$ and $\mathrm{Mn}$ during sample handling may have contributed to elevated $\mathrm{Fe} / \mathrm{Al}$ and $\mathrm{Mn} / \mathrm{Al}$. However, since $\mathrm{Al}$ is not redox sensitive and, therefore, is not released from reducing sediment or precipitated within the water column, elevated $\mathrm{pMn} / \mathrm{pAl}$ and $\mathrm{pFe} / \mathrm{pAl}$ ratios are generally indicative of the presence of $\mathrm{Mn}$ and Fe from non-lithogenic sources. In agreement with previous studies (Campbell et al., 1988), both pMn/pAl and pMn increase from crustal-like values in the surface ocean and North Pacific Intermediate Water to highly elevated values in the deep-water within the basin. Elevated $\mathrm{pMn} / \mathrm{pAl}$ ratios relative to UCC are observed both at the vent field site and 
at the basin site. Particulate Fe concentrations increase with depth throughout the water column. In contrast to $\mathrm{pMn} / \mathrm{pAl}$, however, $\mathrm{pFe} / \mathrm{pAl}$ is only elevated at the vent field site, whereas at the basin site, $\mathrm{pFe} / \mathrm{pAl}$ ratios are close to the UCC. Somewhat elevated $\mathrm{pFe} / \mathrm{pAl}$ ratios are observed at intermediate depth, roughly coincident with the OMZ.

\subsection{Sediment pore water}

Pore water profiles of major redox species (Fig. 3) provide information about the intensity of organic matter degradation and the predominant biogeochemical processes in the sediment at the various sites. The layer where nitrate reduction takes place (nitrogenous zone), as revealed by decreasing $\mathrm{NO}_{3}{ }^{-}$concentrations and a transient occurrence of $\mathrm{NO}_{2}{ }^{-}$, becomes progressively thicker from the shelf and slope sites $(\leq 1 \mathrm{~cm}$ ) to the basin and graben sites (up to $5 \mathrm{~cm}$ ). Sediments on the shelf and slope are characterized by elevated pore water Fe concentrations close to the sediment surface (up to 60 $\mu \mathrm{M}$ at $5 \mathrm{~cm}$ at the $\mathrm{OMZ}$ site), whereas at the basin and graben sites slightly elevated $\mathrm{Fe}$ concentrations are observed well below the surface (up to $\sim 10 \mu \mathrm{M}$ at $10 \mathrm{~cm}$ ). Pore water $\mathrm{Mn}$ concentrations are low at the shelf site and within the $\mathrm{OMZ}(<2 \mu \mathrm{M})$ and progressively increase towards the deeper sites, where dissolved Mn concentrations up to $280 \mu \mathrm{M}$ are detected. At the vent field site, relatively high pore water $\mathrm{Mn}$ concentrations (up to $80 \mu \mathrm{M}$ ) are observed in the uppermost $5 \mathrm{~cm}$, whereas below this depth, pore waters are characterized by highly elevated Fe concentrations up to $190 \mu \mathrm{M}$. Hydrogen sulfide is detected below a sediment depth of 10 to $20 \mathrm{~cm}$ within the $\mathrm{OMZ}$, at the $\mathrm{OMZ}$ rim and at the basin site. Downward concentration gradients of $\mathrm{NH}_{4}{ }^{+}$ from decaying organic matter decrease from the slope to the basin. Overall, our observations are indicative of a decreasing intensity of organic matter degradation from the slope to the basin, which is also consistent with decreasing TOC concentrations (Table 1).

At the shelf, $\mathrm{OMZ}, \mathrm{OMZ}$ rim and vent field sites a significant concentration gradient of dissolved Fe between the bottom water and uppermost pore water sample is observed. This gradient can be used to calculate a diffusive benthic flux across the sediment-water interface based on Fick's $1^{\text {st }}$ law of diffusion (Table 3). The benthic fluxes calculated for the $\mathrm{OMZ}$ and $\mathrm{OMZ}$ rim sites are comparable to those reported for other OMZs by the same method (e.g., $<0.1-2 \mu \mathrm{mol} \mathrm{cm}{ }^{-2} \mathrm{yr}^{-1}$ in the OMZs off Peru and Mauritania) (Schroller-Lomnitz et al., 2019). However, due to the coarse depth resolution of pore water profiles and disregard of advective transport, diffusive fluxes are generally associated with a large uncertainty. In-situ benthic fluxes determined at the same site by using benthic incubation chambers tend to be higher (Severmann et al., 2010; Noffke et al., 2012; Lenstra et al., 2019). This general trend could either be related to the shortcomings of diffusive flux calculations, or an artificial drawdown of oxidants during the incubation. A relatively high diffusive benthic Fe flux is calculated for the vent field site (Table 3). 
299

300

301

302

303

304

305

306

307

308

309

310

311

312

313

314

315

316

317

Sedimentary $\mathrm{Mn} / \mathrm{Al}$ exponentially increases from values below the UCC ratio at the shelf and $\mathrm{OMZ}$ sites to values above UCC at the graben site (Fig. 4). The extent of Mn enrichment relative to UCC is about equal at the vent field site and at the basin site. Similar to $\mathrm{Mn} / \mathrm{Al}, \mathrm{Fe}_{\mathrm{T}} / \mathrm{Al}$ increases with water depth (Fig. 4). However, the extent of $\mathrm{Fe}_{\mathrm{T}}$ enrichment relative to UCC at the $\mathrm{OMZ}$ rim, basin and graben sites is less pronounced compared to $\mathrm{Mn}$. Sedimentary $\mathrm{Fe}_{\mathrm{T}} / \mathrm{Al}$ ratios at the vent field site by far exceed the ratios at the basin and graben sites. Sedimentary $\mathrm{Fe}_{\mathrm{HR}} / \mathrm{Fe}_{\mathrm{T}}$ ratios increase from values equal to modern continental margin sediment with oxic bottom water (a data compilation for sediments from Long Island Sound, shallow Baltic Sea, Mississippi Delta and the NW Mediterranean) (Raiswell and Canfield, 1998) at the shelf site to values above this reference value at the remaining sites (Fig. 4). Increasing $\mathrm{Fe}_{\mathrm{HR}} / \mathrm{Fe}_{\mathrm{T}}$ ratios from shelf to basin are accompanied by decreasing Ti/Al ratios. Titanium primarily resides in heavy minerals within the coarse-grained sediment fraction, whereas Al is mainly contained in fine-grained clay minerals (Boyle, 1983). Therefore, decreasing $\mathrm{Ti} / \mathrm{Al}$ ratios are indicative of a decrease in grain size from shelf to basin. Mean Fe isotope values of individual cores increase from the shelf site $\left(\delta^{56} \mathrm{Fe}=+0.07 \pm 0.02 \%, 1 \mathrm{SD}, \mathrm{n}=5\right)$ to the $\mathrm{OMZ}$ site $\left(\delta^{56} \mathrm{Fe}=+0.11 \pm 0.02 \%, 1 \mathrm{SD}, \mathrm{n}=5\right)$ and then decrease between the $\mathrm{OMZ} \mathrm{rim}\left(\delta^{56} \mathrm{Fe}=+0.07 \pm 0.07\right.$ $\%$, $1 \mathrm{SD}, \mathrm{n}=5)$, basin $\left(\delta^{56} \mathrm{Fe}=+0.03 \pm 0.04 \%, 1 \mathrm{SD}, \mathrm{n}=5\right)$ and graben sites $\left(\delta^{56} \mathrm{Fe}=-0.03 \pm 0.02 \%, 1\right.$ $\mathrm{SD}, \mathrm{n}=5$ ) (Fig. 4). Sediments at the vent field site show the lowest Fe isotope values observed in this study (mean $\delta^{56} \mathrm{Fe}=-0.35 \pm 0.03 \%, 1 \mathrm{SD}, \mathrm{n}=5$ ).

\section{Discussion}

\subsection{Sedimentary manganese and iron enrichments in the Guaymas Basin}

Sediments of the Guaymas Basin are enriched in $\mathrm{Mn}, \mathrm{Fe}_{\mathrm{T}}$ and $\mathrm{Fe}_{\mathrm{HR}}$ relative to $\mathrm{UCC}$ and modern continental margin sediments with oxic bottom water (Fig. 4), which could reflect delivery of $\mathrm{Mn}$ and Fe from non-lithogenic sources. Campbell et al. (1988) established a Mn mass balance for sediments in the Guaymas Basin and concluded that sedimentary $\mathrm{Mn}$ enrichments are primarily related to hydrothermal discharge with additional contributions (roughly $25 \%$ ) from sedimentary Mn release at the shelf and slope, followed by downslope transport. Efficient spread of vent-derived $\mathrm{Mn}$ throughout the basin is also indicated by coincident and similar anomalies of $\mathrm{pMn}$ and $\mathrm{pMn} / \mathrm{pAl}$ in hydrothermal plumes and at more distal locations (compare basin and vent field site in Fig. 2) (Campbell and Gieskes, 1984). Manganese oxidation in hydrothermal plumes of the Guaymas Basin is relatively fast and mediated by Mn-oxidizing microbes (Dick et al., 2009). It has been hypothesized that the filamentous morphology of Mn-rich particles resulting from this process facilitates longrange transport and, thus, spread of hydrothermal Mn throughout the basin (Campbell et al., 1988). 
Campbell et al. (1988) did not report sedimentary Fe concentration or speciation data but noted that $\mathrm{pFe}$ in the deep-water of the Guaymas Basin is correlated with lithogenic elements such as Al and Ti. Consistent with this observation, deep-water $\mathrm{pFe} / \mathrm{pAl}$ ratios at the basin site are similar to the ratio of UCC (Fig. 2). According to Campbell et al. (1988), lower concentrations of vent-derived pFe compared to $\mathrm{pMn}$ are related to extensive Fe sulfide precipitation in the sediments and, therefore, relatively low dissolved Fe concentrations and Fe to $\mathrm{Mn}$ ratios in hydrothermal fluids in the Guaymas Basin compared to bare ridge-crest hydrothermal systems (Von Damm et al., 1985). In addition, the pronounced difference in pFe/pAl between the vent field site and basin site (Fig. 2) imply that the spread of vent-derived Fe in the deep water is less efficient compared to Mn.

Pore water profiles at the shelf and slope sites indicate a diffusive flux of Fe across the sedimentwater interface (Fig. 3, Table 3) and elevated pFe/pAl ratios within the $\mathrm{OMZ}$ are consistent with a sedimentary source of $\mathrm{pFe}$. These observations indicate that re-precipitation of sediment-derived Fe and lateral transport of dissolved and/or particulate $\mathrm{Fe}$ is another mechanism that could explain sedimentary Fe enrichments in the Guaymas Basin. In the following discussion, we aim to disentangle sedimentary from hydrothermal contributions to sedimentary Fe enrichments in the Guaymas Basin.

\subsection{Sedimentary versus hydrothermal iron sources}

Transport of non-lithogenic $\mathrm{Fe}_{\mathrm{HR}}$ from a sedimentary or hydrothermal source and accumulation in the basin should result in a characteristic trend of $\mathrm{Fe}_{\mathrm{T}} / \mathrm{Al}$ versus $\mathrm{Fe}_{\mathrm{HR}} / \mathrm{Fe}_{\mathrm{T}}$, which can be calculated using the following set of equations (Scholz, 2018):

$F e_{T} / A l=\frac{M A R \cdot A l \cdot\left(\frac{F e_{T}}{A l}\right)_{i n}+\left(R R_{F e} \cdot M_{F e}\right)}{M A R \cdot A l}$

$F e_{H R} / F e_{T}=\frac{M A R \cdot A l \cdot\left(\frac{F e_{T}}{A l}\right)_{i n} \cdot\left(\frac{F e_{H R}}{F e_{T}}\right)_{i n}+\left(R R_{F e} \cdot M_{F e}\right)}{M A R \cdot A l \cdot\left(\frac{F e_{T}}{A l}\right)_{i n}+\left(R R_{F e} \cdot M_{F e}\right)}$

In these equations, MAR is the sediment mass accumulation rate (in $\mathrm{g} \mathrm{cm}^{-2} \mathrm{yr}^{-1}$ ), Al is the aluminum concentration (in $\left.\mathrm{mg} \mathrm{g}^{-1}\right),\left(\mathrm{Fe}_{\mathrm{T}} / \mathrm{Al}\right)_{\text {in }}$ and $\left(\mathrm{Fe}_{\mathrm{HR}} / \mathrm{Fe}_{\mathrm{T}}\right)_{\text {in }}$ are the initial ratios prior to deposition of nonlithogenic Fe (i.e., corresponding to the terrigenous input), $\mathrm{RR}_{\mathrm{Fe}}$ is the rain rate of non-lithogenic $\mathrm{Fe}$ (in $\mathrm{mmol} \mathrm{cm}^{-2} \mathrm{yr}^{-1}$ ) and $\mathrm{M}_{\mathrm{Fe}}$ is the molar mass of $\mathrm{Fe}\left(55.845 \mathrm{mg} \mathrm{mmol}^{-1}\right.$ ). Adopting a range of $\mathrm{RR}_{\mathrm{Fe}}$ yields a trend line of $\mathrm{Fe}_{\mathrm{T}} / \mathrm{Al}$ versus $\mathrm{Fe}_{\mathrm{HR}} / \mathrm{Fe}_{\mathrm{T}}$ (Fig. 5), which can be used to evaluate whether a 
combination of $\mathrm{Fe}_{\mathrm{T}} / \mathrm{Al}$ and $\mathrm{Fe}_{\mathrm{HR}} / \mathrm{Fe}_{\mathrm{T}}$ can be assigned to a net loss or gain of non-lithogenic reactive $\mathrm{Fe}$. Importantly, the shape of the trend line and its position within the $\mathrm{Fe}_{\mathrm{T}} / \mathrm{Al}$ versus $\mathrm{Fe}_{\mathrm{HR}} / \mathrm{Fe}_{\mathrm{T}}$ space solely depends on $\left(\mathrm{Fe}_{\mathrm{T}} / \mathrm{Al}\right)_{\text {in }}$ and $\left(\mathrm{Fe}_{\mathrm{HR}} / \mathrm{Fe}_{\mathrm{T}}\right)_{\text {in }}$ but are unaffected by MAR, Al and RR $\mathrm{Fe}_{\mathrm{Fe}}$ (see Scholz et al. (2018) for further details). The use of $\mathrm{Fe}_{\mathrm{HR}} / \mathrm{Fe}_{\mathrm{T}}$ and $\mathrm{Fe}_{\mathrm{T}} / \mathrm{Al}$ as sedimentary proxies for non-lithogenic $\mathrm{Fe}$ delivery is based on the notion that reactive Fe minerals that precipitate in the water column are mixed with sediments whose Fe content is determined by terrigenous input. We therefore use the $\mathrm{Fe}_{\mathrm{T}} / \mathrm{Al}$ of UCC $\left(\mathrm{Fe}_{\mathrm{T}} / \mathrm{Al}=0.44\right)$ (McLennan, 2001) and $\mathrm{Fe}_{\mathrm{HR}} / \mathrm{Fe}_{\mathrm{T}}$ of modern continental margin sediments with oxic bottom water $\left(\mathrm{Fe}_{\mathrm{HR}} / \mathrm{Fe}_{\mathrm{T}}=0.28\right)$ (Raiswell and Canfield, 1998) as initial values (open star in Fig. 5). Sediments plotting above and to the right of the terrigenous input have received a net gain of non-lithogenic reactive Fe, whereas sediments plotting below and to the left of the terrigenous input are characterized by a net loss of reactive Fe (e.g., through sedimentary Fe release).

Sediments within the $\mathrm{OMZ}$ and at the $\mathrm{OMZ}$ rim plot along the trend line corresponding to nonlithogenic Fe delivery (Fig. 5). As these sites are located well above the sill (Fig. 2) and, thus, outside of the influence of hydrothermal vents (Campbell et al., 1988), a hydrothermal source of the sedimentary Fe enrichment can be excluded. Reducing sediments on the shelf and slope of the Guaymas Basin release Fe to the water column (Fig. 3 and Table 3) and elevated pFe/pAl within the OMZ (Fig. 2) suggest that sediment-derived Fe is re-precipitated in the water column. We therefore attribute sedimentary Fe enrichments within the $\mathrm{OMZ}$ and at the $\mathrm{OMZ}$ rim to downslope shuttling of sediment-derived Fe. Similar to other continental margin settings, where sedimentary Fe release and downslope shuttling have been reported, Fe enrichments are most pronounced at the boundary between anoxic and oxic bottom waters (i.e., at the OMZ rim site). Following previous studies, we hypothesize that downslope transport is mediated via continuous Fe release, precipitation, deposition and re-release (Scholz et al., 2016). Precipitation of dissolved Fe within the anoxic bottom water may proceed via multiple mechanisms including, e.g., micro-aerophilic and nitrate-dependent Fe oxidation (Konhauser et al., 2011; Raiswell and Canfield, 2012; Scholz et al., 2016). At the lower rim of the $\mathrm{OMZ}$, increasing oxygen and nitrate concentrations in the bottom water (Fig. 2) induce an increased flux of these oxidants into the surface sediment (note steep nitrate gradient at OMZ rim site in Fig. 3). Therefore, a shift from sedimentary Fe release to Fe accumulation takes place (Scholz et al., 2016). In areas where dissolved Fe release is prevented by oxygen and nitrate penetration into the surface sediment, re-suspension of Fe-rich particles at the sediment surface by bottom currents may mediate further downslope transport (Lenstra et al., 2019).

Sediments at the basin and graben sites display elevated $\mathrm{Fe}_{\mathrm{HR}} / \mathrm{Fe}_{\mathrm{T}}$ but the corresponding $\mathrm{Fe}_{\mathrm{T}} / \mathrm{Al}$ ratios are too low to yield a match with the trend line for non-lithogenic Fe delivery (Fig. 5). This Fe 
speciation signature is inconsistent with Fe supply from hydrothermal venting or reducing sediments as the sole sources of excess $\mathrm{Fe}_{\mathrm{HR}}$. We can estimate the fraction of non-lithogenic excess $\mathrm{Fe}_{\mathrm{HR}}$ and lithogenic excess $\mathrm{Fe}_{\mathrm{HR}}$ by comparing observed mean $\mathrm{Fe}_{\mathrm{HR}} / \mathrm{Fe}_{\mathrm{T}}$ with predicted $\mathrm{Fe}_{\mathrm{HR}} / \mathrm{Fe}_{\mathrm{T}}$ based on Equations (1) and (2) (Table 4). At the OMZ and OMZ rim sites, $100 \%$ of the sedimentary Fe enrichments can be attributed to a non-lithogenic source. By contrast, at the Basin and Graben sites, only about $30 \%$ of the excess $\mathrm{Fe}_{\mathrm{HR}}$ may be explained by non-lithogenic Fe delivery whereas the remainder is delivered with a $\mathrm{Fe}_{\mathrm{T}} / \mathrm{Al}$ ratio similar to UCC. Anderson and Raiswell (2004) made a similar observation in the Black Sea. Based on a reactive Fe mass balance, these authors concluded that only about $40 \%$ of the reactive Fe enrichment in the pelagic Black Sea can be explained by release of dissolved Fe from shelf sediments and re-deposition within the deep basin. The remainder was attributed to an unusually high reactivity of the lithogenic Fe delivered to the basin relative to continental margin sediments with oxic bottom water. This finding can be confirmed by comparing the range of $\mathrm{Fe}_{\mathrm{T}} / \mathrm{Al}$ and $\mathrm{Fe}_{\mathrm{HR}} / \mathrm{Fe}_{\mathrm{T}}$ observed in the Black Sea (Raiswell and Canfield, 1998; Lyons and Severmann, 2006) (note, $\mathrm{Fe}_{\mathrm{HR}} / \mathrm{Fe}_{\mathrm{T}}$ and $\mathrm{Fe}_{\mathrm{T}} / \mathrm{Al}$ were determined on different samples) with the trend line for non-lithogenic Fe delivery (Fig. 5). Indeed, much of the data range covered by the Black Sea is located to the right of the trend line, indicating that an important fraction of the reactive $\mathrm{Fe}$ enrichment cannot be assigned to a non-lithogenic source.

Anderson and Raiswell (2004) noted three possible reasons for the unusually high reactivity of the lithogenic Fe supply to the pelagic Black Sea: (1) microbial oxidation of ferrous Fe in primary silicate minerals, (2) microbial reduction of ferric Fe in clay minerals and (3) preferential transport of finegrained and Fe-rich lithogenic material across the shelf and into the basin. Consistent with this latter scenario, most of the $\mathrm{Fe}_{\mathrm{HR}}$ carried by rivers is contained in the fine-grained fraction (Poulton and Raiswell, 2005). It is well established that these fine-grained particles can by-pass the shelf and slope environment, whereas the coarse-grained sediment fraction is generally retained on continental margins (Seibold and Berger, 1993). In a recent study, Lenstra et al. (2019) demonstrated that much of the reactive Fe transport across the Black Sea shelf is mediated by repeated resuspension and deposition of fine-grained particles that are enriched in Fe (oxyhydr)oxide and Fe-rich clay minerals. In the Guaymas Basin, increasing $\mathrm{Fe}_{\mathrm{HR}} / \mathrm{Fe}_{\mathrm{T}}$ ratios from shelf to basin are accompanied by decreasing $\mathrm{Ti} / \mathrm{Al}$ ratios (Fig. 4), the latter of which is indicative of decreasing grain size. We cannot exclude a microbial influence on the reactivity of terrigenous Fe based on our data set. However, considering the clear trend in Ti/Al (Fig. 4) and broad parallels to the Black Sea Fe speciation signature (Fig. 5), we conclude that grain-size fractionation is likely an important mechanism contributing to elevated $\mathrm{Fe}_{\mathrm{HR}} / \mathrm{Fe}_{\mathrm{T}}$ in the Guaymas Basin. 
The non-lithogenic excess $\mathrm{Fe}_{\mathrm{HR}}$ at the basin and graben sites can be derived from hydrothermal venting or sedimentary Fe release on the surrounding shelf and slope. Sediments underneath hydrothermal plumes at mid-ocean ridges are typically enriched in Fe, even far away from the vent field. For example, Cave et al. (2002) observed $\mathrm{Fe}_{\mathrm{T}} / \mathrm{Al}$ ratios of 2.3 to 3.0 within a distance of 2 to 25 $\mathrm{km}$ from the Rainbow hydrothermal field at the Mid-Atlantic Ridge. The basin and graben sites are located at a distance of 12.5 and $5.6 \mathrm{~km}$ from the newly discovered vent field. Therefore, a notable hydrothermal influence on Fe accumulation could be expected. However, sediments underneath the Rainbow hydrothermal plume are located far away from terrigenous sediment sources and are, thus, characterized by very low Al concentrations $\left(\sim 6 \mathrm{mg} \mathrm{g}^{-1}\right)$ and sediment mass accumulation rates $(\sim 2 \mathrm{~g}$ $\mathrm{cm}^{-2} \mathrm{kyr}^{-1}$ ) (Cave et al., 2002). Using a similar approach to the one outlined above (Equation (1)), Cave et al. (2002) estimated a hydrothermal Fe rain rate of $3.7 \cdot 10^{-4}-7.2 \cdot 10^{-4} \mathrm{mmol} \mathrm{cm}^{-2} \mathrm{yr}^{-1}$ for sediments underneath the Rainbow hydrothermal plume. Applying the same non-lithogenic Fe rain rate to sediments of the Guaymas basin, which are characterized by considerably higher Al concentrations ( $\left.\sim 30 \mathrm{mg} \mathrm{g}^{-1}\right)$ and mass accumulation rates ( $\left.280 \mathrm{~g} \mathrm{~cm}^{-2} \mathrm{kyr}^{-1}\right)$ (Calvert et al., 1966), would yield a $\mathrm{Fe}_{\mathrm{T}} / \mathrm{Al}$ of $0.442-0.445$, which is analytically indistinguishable from UCC. Moreover, the upward looking ADCP deployed southeast of the vent field revealed that deep-water currents are predominantly directed in a northeastward direction and, thus, away from the basin and graben sites (Fig. 6). It is therefore questionable whether Fe transported within hydrothermal plumes can contribute to the accumulation of excess $\mathrm{Fe}_{\mathrm{HR}}$ at these locations. The rate of sedimentary Fe release from reducing shelf and slope sediments of $-1.0--5.6 \cdot 10^{-4} \mathrm{mmol} \mathrm{cm}^{-2} \mathrm{yr}^{-1}$ (Table 3) is of the same order as the hydrothermal $\mathrm{Fe}$ rain rate underneath the Rainbow hydrothermal plume. As demonstrated above, much of this sediment-derived Fe is re-precipitated at the OMZ rim close the source. However, the area covered by shelf and slope sediments surrounding the Guyamas Basin is considerably larger than the sink area within the deep basin and offshore export of non-lithogenic Fe is consistent with elevated pFe/pAl in particles below the $\mathrm{OMZ}$ and above the sill (Fig. 2). Therefore, it is likely that both sedimentary Fe release and hydrothermal venting contribute to enrichments of non-lithogenic Fe within the deep Guaymas Basin.

Sediments at the vent field site are characterized by highly elevated $\mathrm{Fe}_{\mathrm{T}} / \mathrm{Al}(>150)$ compared to UCC, while $\mathrm{Fe}_{\mathrm{HR}} / \mathrm{Fe}_{\mathrm{T}}$ ranges from 0.41 to 0.75 (Fig. 4). Extrapolating the trend line of non-lithogenic $\mathrm{Fe}$ delivery (Fig. 5) to highly elevated $\mathrm{Fe}_{\mathrm{T}} / \mathrm{Al}$ reveals that sedimentary $\mathrm{Fe}_{\mathrm{HR}} / \mathrm{Fe}_{\mathrm{T}}$ would have to be $\sim 1$ if all of the excess Fe was present as Fe (oxyhydr)oxide or sulfide minerals that had precipitated from vent fluids. The mismatch indicates that a fraction of the excess Fe at the vent field site is contained in minerals that were not recovered by the sequential extraction. Previous studies demonstrated that hydrothermal fluids in the Guaymas Basin are oversaturated with respect to Fe-rich silicate minerals (e.g., ferrosilite, fayalite, greenalite) (Von Damm et al., 1985). Moreover, Fe-rich silicate minerals 
were identified in plume particles at other hydrothermal vent fields (Gartman et al., 2014). We, therefore, assume that an important fraction of the hydrothermally derived Fe at the vent field site is present in Fe-rich silicate minerals.

\subsection{Isotopic fingerprint of the shelf-to-basin iron shuttle in the Guaymas Basin}

Previous studies in semi-restricted euxinic basins (Black Sea, Gotland Deep in the Baltic Sea) (Severmann et al., 2008; Fehr et al., 2008) and on the open-marine Peruvian continental margin (Scholz et al., 2014b) found that Fe shuttling in these systems is associated with characteristic Fe isotopic fingerprints. These fingerprints, i.e., the regression slopes between source and sink area, can be used as a framework for the interpretation of Fe isotope variability in the Guaymas Basin (Fig. 7A) (note, Black Sea and Gotland Deep (not shown) trends are essentially identical).

In euxinic basins, increasing $\mathrm{Fe}_{\mathrm{T}} / \mathrm{Al}$ ratios from shelf to basin are accompanied by decreasing $\delta^{56} \mathrm{Fe}$, which overall results in a negative correlation between these two parameters. Reductive $\mathrm{Fe}$ dissolution within marine sediments preferentially mobilizes the light Fe isotope (e.g., Severmann et al., 2006; Staubwasser et al., 2006; Rouxel et al., 2008a; Homoky et al., 2009) and the Fe efflux from reducing sediments, therefore, has a light Fe isotope composition relative to average igneous rocks (Severmann et al., 2010). Using this light isotope composition as a conservative source signature, the light Fe isotopic fingerprint of sedimentary Fe enrichments in the Black Sea basin (Fig. 7A) was assigned to lateral Fe supply from reducing shelf sediments (Severmann et al., 2008). On the Peruvian continental margin, sedimentary Fe enrichments below the lower boundary of the OMZ are isotopically heavier than sediments within the OMZ (Fig. 7A) (Scholz et al., 2014b), where reactive Fe is reductively mobilized across the sediment-water interface (Noffke et al., 2012). In the sink area below the $\mathrm{OMZ}$, reactive Fe is deposited as Fe (oxyhydr)oxide and transformed to authigenic silicate minerals (mainly glauconite) during early diagenesis (Scholz et al., 2014c). Most experimental and field studies found that precipitation of $\mathrm{Fe}$ (oxyhydr)oxides from aqueous $\mathrm{Fe}(\mathrm{II})$ results in an isotopically heavy Fe precipitate (e.g., Bullen et al., 2001; Croal et al.,2004; Rouxel et al., 2008a; Busigny et al., 2014; Chever et al., 2015). Assuming that only a fraction of the Fe transported downslope is retained and buried below the OMZ, Scholz et al. (2014b) attributed the positive correlation between $\mathrm{Fe}_{\mathrm{T}} / \mathrm{Al}$ and $\delta^{56} \mathrm{Fe}$ across the continental margin to non-quantitative reprecipitation of sediment-derived Fe as Fe (oxyhydr)oxide below the OMZ and offshore transport of the remaining Fe. This scenario was later supported by John et al. (2018), who reported a plume of isotopically light dissolved Fe emanating from the Peruvian continental margin into the open Pacific well below the depth of the OMZ (1000 - $3000 \mathrm{~m}$ water depth). 
491 The range of $\delta^{56} \mathrm{Fe}$ observed in Guaymas Basin sediments is smaller than observed for sediments 492 from the Black Sea and Peruvian continental margin (note differing axes scales in Figs. 7A and B). Iron 493 isotope data for the Guaymas Basin plot within a triangle defined by the regression slopes of the $494 \mathrm{Fe}_{\mathrm{T}} / \mathrm{Al}$ versus $\delta^{56} \mathrm{Fe}$ relationships observed in the Black Sea and on the Peruvian continental margin 495 (Fig. 7B) (the average $\mathrm{Fe}_{\mathrm{T}} / \mathrm{Al}$ and $\delta^{56} \mathrm{Fe}$ of the shelf site is used as the intercept point). This 496 observation may be indicative of similar fractionation mechanisms. Data from the OMZ and OMZ rim 497 sites plot close to the regression line of Peru margin data. Sedimentary Fe release followed by lateral 498 Fe transport and partial re-deposition or retention (Scholz et al., 2014b) at these sites is consistent 499 with the decrease in benthic Fe efflux and slight increase in sedimentary Fe enrichment from OMZ 500 site to OMZ rim site (Table 3, Fig. 4 and 5). Data from the basin and graben sites plot closer to the 501 regression line of Black Sea data. Part of this trend can be related to an accumulation of isotopically 502 light Fe that was released from sediments on the surrounding shelfs and slopes. Much like in the 503 pelagic Black Sea, any Fe supplied from the surrounding shelfs and slopes cannot escape burial in the 504 basin. Therefore, this $\mathrm{Fe}$ is likely to have a relatively low $\delta^{56} \mathrm{Fe}$ value that reflects its sedimentary 505 source. In addition to this redox-related isotope signature, preferential transport of fine-grained and $506 \mathrm{Fe}_{\mathrm{HR}}$-rich terrigenous particles into the basin or microbial conversion of silicate minerals to $\mathrm{Fe}$ 507 (oxyhydr)oxide or sulfide minerals (see previous section) may also contribute to the light Fe isotope 508 composition of sediments in the Guaymas Basin (and the Black Sea). Such a scenario is supported by 509 studies on Fe isotope fractionation in soils, which demonstrated that weathering processes 510 preferentially transfer the light Fe isotopes from primary silicate minerals to fine-grained secondary 511 clay and (oxyhydr)oxide minerals (Wiederhold et al., 2007; Kiczka et al., 2010, 2011).

512 Another potential source of isotopically light Fe to basin sediments is hydrothermal venting. 513 Sediments at the vent field site, which consist mostly of black smoker debris, have a $\delta^{56} \mathrm{Fe}$ of $\sim-0.39$ 514 to $-0.31 \%$. These values are within the range of $\delta^{56} \mathrm{Fe}$ values for vent fluids from bare rock 515 hydrothermal systems (e.g., Severmann et al., 2004; Bennett et al., 2009; Rouxel et al., 2008b, 2016). 516 In a plot of $\delta^{56} \mathrm{Fe}$ versus $\mathrm{Al} / \mathrm{Fe}_{\mathrm{T}}$, most of the sediment samples from the basin and graben sites plot on 517 a line between the average values of the shelf and vent field sites (Fig. 8). The corresponding mixing 518 relationship implies that the $\mathrm{Fe}$ isotope composition of sediments at the graben site could theoretically be explained by binary mixing between shelf sediments (70 - $80 \%$ ) and hydrothermal Fe that has not been isotopically fractionated by reaction with sediments (20 - 30\%). While a maximum proportion of $\sim 30 \%$ non-lithogenic Fe at the graben site supports our other, independent estimate from the $\mathrm{Fe}_{\mathrm{T}} / \mathrm{Al}$ versus $\mathrm{Fe}_{\mathrm{HR}} / \mathrm{Fe}_{\mathrm{T}}$ relationship in Fig. 6 (Table 4), we note that the isotope composition of hydrothermally sourced Fe may be moderated as the vent fluids pass through sediments and the $\delta^{56} \mathrm{Fe}$ value of vent fluids discharged at the seafloor is unknown. Moreoever, the isotope composition of the hydrothermally sourced Fe that is transported within hydrothermal plumes is expected to 
526 change as a result of Fe (oxyhydr)oxide $\left(\delta^{56} \mathrm{Fe}\right.$ of dissolved Fe decreases) or Fe sulfide $\left(\delta^{56} \mathrm{Fe}\right.$ of 527 dissolved Fe increases) precipitation (Rouxel et al., 2016; Lough et al., 2017). Any vent-derived Fe 528 accumulating at the basin and graben sites is, thus, unlikely to have the same isotope composition as 529 the smoker debris at the vent field site. Furthermore, it should be noted that the offshore dissolved 530 Fe plume on the Peruvian margin reported by John et al. (2018) has essentially the same isotope composition as hydrothermal sediments at the vent field site $\left(\delta^{56} \mathrm{Fe}=\sim-0.2--0.5 \%\right.$ ). Considering these arguments and the fact that bottom currents at the vent field site are predominantly directed away from the graben and basin sites (Fig. 6), we argue that hydrothermal contributions to the isotope signal are likely to be of minor importance.

\subsection{Implications for the interpretation of iron-based paleo-proxies}

Sedimentary Fe speciation has been widely used to identify anoxic $\left(\mathrm{Fe}_{\mathrm{HR}} / \mathrm{Fe}_{\mathrm{T}}>0.22-0.38\right)$ and ferruginous $\left(\mathrm{Fe}_{\mathrm{py}} / \mathrm{Fe}_{\mathrm{HR}}<0.7-0.8\right)$ or euxinic $\left(\mathrm{Fe}_{\mathrm{py}} / \mathrm{Fe}_{\mathrm{HR}}>0.7-0.8\right)$ conditions in the water column at the time of deposition (Fig. 9) (Poulton and Canfield, 2011; Raiswell and Canfield, 2012). Sediments in the Guaymas Basin have a Fe speciation signature that is indicative of ferruginous depositional conditions (Fig. 9), theoretically implying that dissolved ferrous Fe dominates over oxygen, nitrate and hydrogen sulfide in the water column (Poulton and Canfield, 2011; Raiswell and Canfield, 2012). In contrast to this notion, however, bottom water redox conditions in the reactive Fe source and sink areas are weakly oxic to anoxic and nitrate-reducing $\left(\mathrm{O}_{2}: 0-40 \mu \mathrm{M}, \mathrm{NO}_{3}{ }^{-}: \geq 30 \mu \mathrm{M}\right)$ (Fig. 2). Similar to the Black Sea (Anderson and Raiswell, 2004), an important fraction of the lateral displacement of reactive $\mathrm{Fe}$ is not related to Fe precipitation in the water column but rather to grain size fractionation or microbially mediated conversion of non-reactive silicate minerals to reactive Fe (oxyhydr)oxide minerals. These observations highlight that reactive Fe enrichments in ancient sediments and sedimentary rocks can imply more diverse environmental conditions than is captured by the terms 'ferruginous' and 'euxinic'. The trend line for non-lithogenic Fe delivery used in this study can be applied to identify those diverse environmental conditions in the paleo-record.

\section{Summary and conclusions}

Sediments in the Guaymas basin are enriched in reactive Fe relative to terrigenous material and continental margin sediments with oxic bottom water. The following processes may contribute to the net accumulation of reactive Fe in sediments on the slope and within the basin:

(1) Release of dissolved Fe from reducing shelf and slope sediments followed by lateral transport of dissolved and/or particulate Fe in the water column. 
557 (2) Preferential transfer of fine-grained terrigenous particles that are rich in reactive Fe into the 558 basin.

559 (3) Microbially mediated conversion of non-reactive silicate minerals to reactive Fe minerals during 560 transport.

561 (4) Discharge of Fe at hydrothermal vents and lateral transport of dissolved and/or particulate Fe 562 within the deep water.

563 The first process can explain reactive Fe enrichments in sediment at the Guaymas basin slope 564 whereas all processes may contribute to sedimentary Fe enrichments within the deep basin. Shuttle565 related Fe speciation and isotope signals in the Guaymas Basin are relatively small compared to those 566 in Black Sea and Peru margin sediments. This difference is mainly related to the higher mass 567 accumulation rate of terrigenous material (Guaymas Basin: $\sim 280 \mathrm{~g} \mathrm{~cm}^{-2} \mathrm{kyr}^{-1}$; Black Sea: $\sim 5 \mathrm{~g} \mathrm{~cm}^{-2} \mathrm{kyr}^{-}$

568 1; Peru margin: $50 \mathrm{~g} \mathrm{~cm}^{-2} \mathrm{kyr}^{-1}$ ) (Calvert et al., 1966. Calvert et al., 1991; Scholz et al., 2011). Due to 569 the higher background sedimentation rate, a similar flux of excess reactive Fe generates a smaller 570 signal in $\mathrm{Fe}_{\mathrm{T}} / \mathrm{Al}, \mathrm{Fe}_{\mathrm{HR}} / \mathrm{Fe}_{\mathrm{T}}$ and $\delta^{56} \mathrm{Fe}$ (Scholz, 2018). Iron isotope data of sediments in the Guaymas 571 Basin reflect the same fractionation mechanisms that were found to be associated with Fe shuttling 572 in the Black Sea and on the Peruvian margin. This observation confirms that redox conditions in the 573 source (Black Sea: oxic; Peru margin and Gulf of California: oxic to anoxic and nitrate-reducing) or 574 sink (Black Sea: euxinic; Peru margin and Gulf of California: oxic) area are of subordinate importance 575 for the generation of a shuttle-related sedimentary fingerprint. Instead, the degree of bathymetric 576 restriction and rate of terrigenous sedimentation dictate whether a resolvable imprint of the shelf577 to-basin Fe shuttle is generated or not.

\section{Acknowledgements}

579 We wish to thank the crew of RV Sonne for supporting our research at sea as well as our colleagues 580 Regina Surberg, Annika Fiskal, Antje Beck, Anna-Kathrin Retschko, Anke Bleyer and Bettina Domeyer 581 for support in the laboratory. This study was funded by the German Research Foundation through 582 the Emmy Noether Nachwuchsforschergruppe ICONOX ("Iron Cycling in Continental Margin 583 Sediments and the Nutrient and Oxygen Balance of the Ocean") to FS and by the German Ministry of 584 Education and Research through the MAKS project. Thoughtful comments from two reviewers and 585 the associate editor Rachael James are gratefully acknowledged.

\section{References} iron in euxinic Black Sea sediments. American Journal of Science 304, 203-233. 
Beard, B.L., Johnson, C.M., Skulan, J.L., Nealson, K.H., Cox, L. and Sun, H. (2003) Application of Fe isotopes to tracing the geochemical and biological cycling of Fe. Chemical Geology 195, 87-117.

Bennett, S.A., Rouxel, O., Schmidt, K., Garbe-Schönberg, D., Statham, P.J. and German, C.R. (2009) Iron isotope fractionation in a buoyant hydrothermal plume, $5^{\circ} \mathrm{S}$ Mid-Atlantic Ridge. Geochimica et Cosmochimica Acta 73, 5619-5634.

Berndt, C., Hensen, C., Mortera-Gutierrez, C., Sarkar, S., Geilert, S., Schmidt, M., Liebetrau, V., Kipfer,

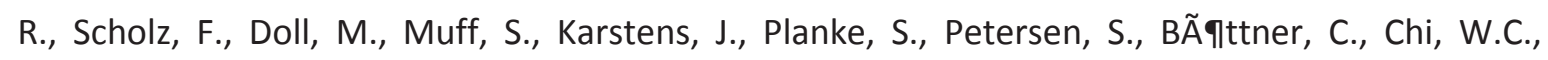
Moser, M., Behrendt, R., Fiskal, A., Lever, M.A., Su, C.C., Deng, L., Brennwald, M.S. and Lizarralde, D. (2016) Rifting under steam - How rift magmatism triggers methane venting from sedimentary basins. Geology 44, 767-770.

Boyd, P.W. and Ellwood, M.J. (2010) The biogeochemical cycle of iron in the ocean. Nature Geosci 3, 675-682.

Boyle, E.A. (1983) Chemical accumulation variations under the Peru Current during the past 130,000 years. Journal of Geophysical Research: Oceans 88, 7667-7680.

Bray, N.A. (1988) Water mass formation in the Gulf of California. Journal of Geophysical Research: Oceans 93, 9223-9240.

Bullen, T.D., White, A.F., Childs, C.W., Vivit, D.V. and Schulz, M.S. (2001) Demonstration of significant abiotic iron isotope fractionation in nature. Geology 29, 699-702.

Busigny, V., Planavsky, N.J., Jezequel, D., Crowe, S., Louvat, P., Moureau, J., Viollier, E. and Lyons, T.W. (2014) Iron isotopes in an Archean ocean analogue. Geochimica et Cosmochimica Acta 133, 443-462.

Calvert, S. (1966) Accumulation of diatomaceous silica in the sediments of the Gulf of California. Geological Society of America Bulletin 77, 569-596.

Calvert, S.E., Karlin, R.E., Toolin, L.J., Donahue, D.J., Southon, J.R. and Vogel, J.S. (1991) Low organic carbon accumulation rates in Black Sea sediments. Nature 350, 692.

Campbell, A.C. and Gieskes, J.M. (1984) Water column anomalies associated with hydrothermal activity in the Guaymas Basin, Gulf of California. Earth and Planetary Science Letters 68, 57-72.

Campbell, A.C., Gieskes, J.M., Lupton, J.E. and Lonsdale, P.F. (1988) Manganese geochemistry in the Guaymas Basin, Gulf of California. Geochimica et Cosmochimica Acta 52, 345-357.

Canfield, D.E., Raiswell, R., Westrich, J.T., Reaves, C.M. and Berner, R.A. (1986) The use of chromium reduction in the analysis of reduced inorganic sulfur in sediments and shales. Chemical Geology 
Cave, R.R., German, C.R., Thomson, J. and Nesbitt, R.W. (2002) Fluxes to sediments underlying the Rainbow hydrothermal plume at $36^{\circ} 14^{\prime} \mathrm{N}$ on the Mid-Atlantic Ridge. Geochimica et Cosmochimica Acta 66, 1905-1923.

Chever, F., Rouxel, O.J., Croot, P.L., Ponzevera, E., Wuttig, K. and Auro, M. (2015) Total dissolvable and dissolved iron isotopes in the water column of the Peru upwelling regime. Geochimica et Cosmochimica Acta 162, 66-82.

Conway, T.M. and John, S.G. (2014) Quantification of dissolved iron sources to the North Atlantic Ocean. Nature 511, 212-215.

Craddock, P.R. and Dauphas, N. (2010) Iron Isotopic Compositions of Geological Reference Materials and Chondrites. Geostandards and Geoanalytical Research 35, 101-123.

Croal, L.R., Johnson, C.M., Beard, B.L. and Newman, D.K. (2004) Iron isotope fractionation by Fe(II)oxidizing photoautotrophic bacteria. Geochimica et Cosmochimica Acta 68, 1227-1242.

Cutter, G., Casciotti, K., Croot, P., Geibert, W., Heimbürger, L.-E., Lohan, M., Planquette, H., van der Flierdt, T. (2017) Sampling and Sample-handling Protocols for GEOTRACES Cruises. Version 3.0.

Dale, A.W., Nickelsen, L., Scholz, F., Hensen, C., Oschlies, A. and Wallmann, K.C.G. (2015) A revised global estimate of dissolved iron fluxes from marine sediments. Global Biogeochemical Cycles 10.1002/2014GB005017.

Dick, G.J., Clement, B.G., Webb, S.M., Fodrie, F.J., Bargar, J.R. and Tebo, B.M. (2009) Enzymatic microbial $\mathrm{Mn}(\mathrm{II})$ oxidation and $\mathrm{Mn}$ biooxide production in the Guaymas Basin deep-sea hydrothermal plume. Geochimica et Cosmochimica Acta 73, 6517-6530.

Elrod, V.A., Berelson, W.M., Coale, K.H. and Johnson, K.S. (2004) The flux of iron from continental shelf sediments: A missing source for global budgets. Geophys. Res. Lett. 31.

Falkowski, P.G. (1997) Evolution of the nitrogen cycle and its influence on the biological sequestration of $\mathrm{CO} 2$ in the ocean. Nature 387, 272-275.

Fehr, M.A., Andersson, P.S., Hålenius, U. and Mörth, C.-M. (2008) Iron isotope variations in Holocene sediments of the Gotland Deep, Baltic Sea. Geochimica et Cosmochimica Acta 72, 807-826.

Gartman, A., Findlay, A.J. and Luther, G.W. (2014) Nanoparticulate pyrite and other nanoparticles are a widespread component of hydrothermal vent black smoker emissions. Chemical Geology 366, 32-41.

Geilert, S., Hensen, C., Schmidt, M., Liebetrau, V., Scholz, F., Doll, M., Deng, L., Fiskal, A., Lever, M.A., Su, C.C., Schloemer, S., Sarkar, S., Thiel, V. and Berndt, C. (2018) On the formation of 
hydrothermal vents and cold seeps in the Guaymas Basin, Gulf of California. Biogeosciences 15, 5715-5731.

Grasshoff, M., Erhard, M. and Kremling, K. (1999) Methods of Seawater Analysis. Wiley-VCH, Weinheim.

Gruber, N. and Sarmiento, J.L. (1997) Global patterns of marine nitrogen fixation and denitrification. Global Biogeochemical Cycles 11, 235-266.

Homoky, W.B., Severmann, S., Mills, R.A., Statham, P.J. and Fones, G.R. (2009) Pore-fluid Fe isotopes reflect the extent of benthic Fe redox recycling: Evidence from continental shelf and deep-sea sediments. Geology 37, 751-754.

Jickells, T.D., An, Z.S., Andersen, K.K., Baker, A.R., Bergametti, G., Brooks, N., Cao, J.J., Boyd, P.W., Duce, R.A., Hunter, K.A., Kawahata, H., Kubilay, N., laRoche, J., Liss, P.S., Mahowald, N., Prospero, J.M., Ridgwell, A.J., Tegen, I. and Torres, R. (2005) Global iron connections between desert dust, ocean biogeochemistry, and climate. Science 308, 67-71.

John, S.G., Helgoe, J., Townsend, E., Weber, T., DeVries, T., Tagliabue, A., Moore, K., Lam, P., Marsay, C.M. and Till, C. (2018) Biogeochemical cycling of Fe and Fe stable isotopes in the Eastern Tropical South Pacific. Marine Chemistry 201, 66-76.

Kiczka, M., Wiederhold, J.G., Frommer, J., Kraemer, S.M., Bourdon, B. and Kretzschmar, R. (2010) Iron isotope fractionation during proton- and ligand-promoted dissolution of primary phyllosilicates. Geochimica et Cosmochimica Acta 74, 3112-3128.

Kiczka, M., Wiederhold, J.G., Frommer, J., Voegelin, A., Kraemer, S.M., Bourdon, B. and Kretzschmar, R. (2011) Iron speciation and isotope fractionation during silicate weathering and soil formation in an alpine glacier forefield chronosequence. Geochimica et Cosmochimica Acta 75, 5559-5573.

Kondo, Y. and Moffett, J.W. (2015) Iron redox cycling and subsurface offshore transport in the eastern tropical South Pacific oxygen minimum zone. Marine Chemistry 168, 95-103.

Konhauser, K.O., Kappler, A. and Roden, E.E. (2011) Iron in Microbial Metabolism. ELEMENTS 7, 8993.

Lenstra, W.K., Hermans, M., Séguret, M.J.M., Witbaard, R., Behrends, T., Dijkstra, N., van Helmond, N.A.G.M., Kraal, P., Laan, P., Rijkenberg, M.J.A., Severmann, S., Teacă, A. and Slomp, C.P. (2018) The shelf-to-basin iron shuttle in the Black Sea revisited. Chemical Geology. 
680

681

682

683

684

685

686

687

688

689

690

691

692

693

694

695

696

697

698

699

700

701

702

703

704

705

706

707

708

Linke, P., Schmidt, M., Rohleder, M., Al-Barakati, A. and Al-Farawati, R. (2015) Novel Online Digital Video and High-Speed Data Broadcasting via Standard Coaxial Cable Onboard Marine Operating Vessels. Marine Technology Society Journal 49, 7-18.

Lohan, M.C. and Bruland, K.W. (2008) Elevated Fe(II) and dissolved Fe in hypoxic shelf waters off Oregon and Washington: An enhanced source of iron to coastal upwelling regimes. Environ. Sci. Technol. 42, 6462-6468.

Lough, A.J.M., Klar, J.K., Homoky, W.B., Comer-Warner, S.A., Milton, J.A., Connelly, D.P., James, R.H. and Mills, R.A. (2017) Opposing authigenic controls on the isotopic signature of dissolved iron in hydrothermal plumes. Geochimica et Cosmochimica Acta 202, 1-20.

Lyons, T.W. and Severmann, S. (2006) A critical look at iron paleoredox proxies: New insights from modern euxinic marine basins. Geochimica et Cosmochimica Acta 70, 5698-5722.

Marinone, S. (2003) A three-dimensional model of the mean and seasonal circulation of the Gulf of California. Journal of Geophysical Research: Oceans 108, doi:10.1029/2002JC001720.

Martínez-García, A., Sigman, D.M., Ren, H., Anderson, R.F., Straub, M., Hodell, D.A., Jaccard, S.L., Eglinton, T.I. and Haug, G.H. (2014) Iron Fertilization of the Subantarctic Ocean During the Last Ice Age. Science 343, 1347-1350.

McLennan, S.M. (2001) Relationships between the trace element composition of sedimentary rocks and upper continental crust. Geochem. Geophys. Geosyst. 2.

Moore, D.G. and Curray, J.R. (1982) Geologic and tectonic history of the Gulf of California, Initial Reports of the Deep Sea Drilling Project, vol. 64. U.S. Govt. Printing Office, Washington.

Moore, J.K. and Braucher, O. (2008) Sedimentary and mineral dust sources of dissolved iron to the world ocean. Biogeosciences 5, 631-656.

Moore, J.K. and Doney, S.C. (2007) Iron availability limits the ocean nitrogen inventory stabilizing feedbacks between marine denitrification and nitrogen fixation. Global Biogeochemical Cycles 21, GB2001, doi:2010.1029/2006GB002762.

Noble, A.E., Lamborg, C.H., Ohnemus, D.C., Lam, P.J., Goepfert, T.J., Measures, C.I., Frame, C.H., Casciotti, K.L., DiTullio, G.R., Jennings, J. and Saito, M.A. (2012) Basin-scale inputs of cobalt, iron, and manganese from the Benguela-Angola front to the South Atlantic Ocean. Limnology and Oceanography 57, 989-1010. 
Noffke, A., Hensen, C., Sommer, S., Scholz, F., Bohlen, L., Mosch, T., Graco, M. and Wallmann, K. (2012) Benthic iron and phosphorus fluxes across the Peruvian oxygen minimum zone. Limnology and Oceanography 57, 851-867.

Poulton, S.W. and Canfield, D.E. (2005) Development of a sequential extraction procedure for iron: implications for iron partitioning in continentally derived particulates. Chemical Geology 214, 209221.

Poulton, S.W. and Canfield, D.E. (2011) Ferruginous conditions: A dominant feature of the ocean through Earth's history. ELEMENTS 7, 107-112.

Raiswell, R. and Anderson, T.F. (2005) Reactive iron enrichment in sediments deposited beneath euxinic bottom waters: constraints on supply by shelf recycling. Geological Society, London, Special Publications 248, 179-194.

Raiswell, R. and Canfield, D.E. (1998) Sources of iron for pyrite formation in marine sediments. American Journal of Science 298, 219-245.

Raiswell, R. and Canfield, D.E. (2012) The iron biogeochemical cycle past and present. Geochemical Perspectives 1, 1-220.

Resing, J.A., Sedwick, P.N., German, C.R., Jenkins, W.J., Moffett, J.W., Sohst, B.M. and Tagliabue, A. (2015) Basin-scale transport of hydrothermal dissolved metals across the South Pacific Ocean. Nature 523, 200-203.

Rouxel, O., Sholkovitz, E., Charette, M. and Edwards, K.J. (2008a) Iron isotope fractionation in subterranean estuaries. Geochimica et Cosmochimica Acta 72, 3413-3430.

Rouxel, O., Shanks, W.C., Bach, W. and Edwards, K.J. (2008b) Integrated Fe- and S-isotope study of seafloor hydrothermal vents at East Pacific Rise 9-10 N. Chemical Geology 252, 214-227.

Rouxel, O., Toner, B.M., Manganini, S.J. and German, C.R. (2016) Geochemistry and iron isotope systematics of hydrothermal plume fall-out at East Pacific Rise $9^{\circ} 50^{\prime} \mathrm{N}$. Chemical Geology 441 , 212-234.

Schoenberg, R. and von Blanckenburg, F. (2005) An assessment of the accuracy of stable Fe isotope ratio measurements on samples with organic and inorganic matrices by high-resolution multicollector ICP-MS. International Journal of Mass Spectrometry 242, 257-272.

Scholz, F. (2018) Identifying oxygen minimum zone-type biogeochemical cycling in Earth history using inorganic geochemical proxies. Earth-Science Reviews 184, 29-45. 
Scholz, F., Hensen, C., Noffke, A., Rohde, A., Liebetrau, V. and Wallmann, K. (2011) Early diagenesis of redox-sensitive trace metals in the Peru upwelling area: response to ENSO-related oxygen fluctuations in the water column. Geochimica et Cosmochimica Acta 75, 7257-7276.

Scholz, F., McManus, J., Mix, A.C., Hensen, C. and Schneider, R.R. (2014a) The impact of ocean deoxygenation on iron release from continental margin sediments. Nature Geoscience 7, 433-437.

Scholz, F., Severmann, S., McManus, J. and Hensen, C. (2014b) Beyond the Black Sea paradigm: The sedimentary fingerprint of an open-marine iron shuttle. Geochimica et Cosmochimica Acta 127, 368-380.

Scholz, F., Severmann, S., McManus, J., Noffke, A., Lomnitz, U. and Hensen, C. (2014c) On the isotope composition of reactive iron in marine sediments: Redox shuttle versus early diagenesis. Chemical Geology 389, 48-59.

Scholz, F., Löscher, C.R., Fiskal, A., Sommer, S., Hensen, C., Lomnitz, U., Wuttig, K., Göttlicher, J., Kossel, E., Steininger, R. and Canfield, D.E. (2016) Nitrate-dependent iron oxidation limits iron transport in anoxic ocean regions. Earth and Planetary Science Letters 454, 272-281.

Schroller-Lomnitz, U., Hensen, C., Dale, A.W., Scholz, F., Clemens, D., Sommer, S., Noffke, A. and Wallmann, K. (2019) Dissolved benthic phosphate, iron and carbon fluxes in the Mauritanian upwelling system and implications for ongoing deoxygenation. Deep Sea Research Part I: Oceanographic Research Papers 143, 70-84.

Seibold, E. and W.H., B. (1993) The Sea Floor. Springer, Berlin.

Severmann, S., Johnson, C.M., Beard, B.L., German, C.R., Edmonds, H.N., Chiba, H. and Green, D.R.H. (2004) The effect of plume processes on the Fe isotope composition of hydrothermally derived Fe in the deep ocean as inferred from the Rainbow vent site, Mid-Atlantic Ridge, 36 degrees 14' N. Earth and Planetary Science Letters 225, 63-76.

Severmann, S., Johnson, C.M., Beard, B.L. and McManus, J. (2006) The effect of early diagenesis on the $\mathrm{Fe}$ isotope compositions of porewaters and authigenic minerals in continental margin sediments. Geochimica Et Cosmochimica Acta 70, 2006-2022.

Severmann, S., Lyons, T.W., Anbar, A., McManus, J. and Gordon, G. (2008) Modern iron isotope perspective on the benthic iron shuttle and the redox evolution of ancient oceans. Geology 36, 487-490.

Severmann, S., McManus, J., Berelson, W.M. and Hammond, D.E. (2010) The continental shelf benthic iron flux and its isotope composition. Geochimica et Cosmochimica Acta 74, 3984-4004. 
Simoneit, B.R.T., Kawka, O.E. and Brault, M. (1988) Origin of gases and condensates in the Guaymas Basin hydrothermal system (Gulf of California). Chem. Geol. 71, 169-182.

Staubwasser, M., von Blanckenburg, F. and Schoenberg, R. (2006) Iron isotopes in the early marine diagenetic iron cycle. Geology 34, 629-632.

Stookey, L.L. (1970) Ferrozine - a new spectrophotometric reagent for iron. Analytical Chemistry 42, 779-781.

Tagliabue, A., Bopp, L., Dutay, J.-C., Bowie, A.R., Chever, F., Jean-Baptiste, P., Bucciarelli, E., Lannuzel, D., Remenyi, T., Sarthou, G., Aumont, O., Gehlen, M. and Jeandel, C. (2010) Hydrothermal contribution to the oceanic dissolved iron inventory. Nature Geosci 3, 252-256.

Tagliabue, A., Bowie, A.R., Boyd, P.W., Buck, K.N., Johnson, K.S. and Saito, M.A. (2017) The integral role of iron in ocean biogeochemistry. Nature 543, 51-59.

Thunell, R., Pride, C., Tappa, E. and Muller-Karger, F. (1993) Varve formation in the Gulf of California: Insights from time series sediment trap sampling and remote sensing. Quaternary Science Reviews 12, 451-464.

Thunell, R.C. (1998) Seasonal and annual variability in particle fluxes in the Gulf of California: A response to climate forcing. Deep Sea Research Part I: Oceanographic Research Papers 45, 20592083.

Von Damm, K.L., Edmond, J.M., Measures, C.I. and Grant, B. (1985) Chemistry of submarine hydrothermal solutions at Guaymas Basin, Gulf of California. Geochimica et Cosmochimica Acta 49, 2221-2237.

White, A.E., Foster, R.A., Benitez-Nelson, C.R., Masqué, P., Verdeny, E., Popp, B.N., Arthur, K.E. and Prahl, F.G. (2013) Nitrogen fixation in the Gulf of California and the Eastern Tropical North Pacific. Progress in Oceanography 109, 1-17.

Wiederhold, J.G., Teutsch, N., Kraemer, S.M., Halliday, A.N. and Kretzschmar, R. (2007) Iron isotope fractionation in oxic soils by mineral weathering and podzolization. Geochimica et Cosmochimica Acta 71, 5821-5833.

\section{Figure captions}

Figure 1. (A) Bathymetric map of the Guaymas Basin within the Gulf of California (bathymetric data from GEBCO). Sampling stations are depicted by stars (multiple corer), yellow-filled circles (CTD rosette) and green-filled circles (ADCP lander). The location of DSDP Site 480 within the OMZ and DSDP Site 477 within the hydrothermal vent field of the southern trough are shown as well. Water 
and sediment sampling was conducted along two transects on the eastern slope of the Guaymas Basin (B) and across the basin and northern trough (C).

Figure 2. Water column profiles of salinity, temperature, oxygen (sensor measurement) and turbidity at the graben site as well as composite profiles of oxygen (Winkler titration), nitrate deficit relative to phosphate $\left(\mathrm{N}^{*}=\mathrm{NO}_{3}{ }^{-}-16 \times \mathrm{PO}_{4}{ }^{3-}\right)$, turbidity as well as particulate $\mathrm{Mn}$ to $\mathrm{Al}(\mathrm{pMn} / \mathrm{pAl}$ in $\mathrm{mg} / \mathrm{mg})$ and Fe to $\mathrm{Al}$ (pFe/pAl in $\mathrm{mg} / \mathrm{mg}$ ) ratios at multiple sites. Vertical solid lines depict the $\mathrm{pMn} / \mathrm{pAl}$ and $\mathrm{pFe} / \mathrm{pAl}$ of the upper continental crust (McLennan, 2001). Particulate Mn and Fe concentrations are shown in inlet diagrams. Strongly deviating values of turbidity, $\mathrm{pFe} / \mathrm{pAl}$ and $\mathrm{pFe}$ (red diamonds) at the vent field site are shown with a separate x-axis. Horizontal arrows depict the water depth of sediment cores (Table 1). Horizontal dashed lines depict the depth of the water mass boundary between North Pacific Intermediate Water and Pacific Deep-water and the depth of the sill that separates Guaymas Basin from Carmen Basin. The data shown in this figure are contained in the Electronic Annex.

Figure 3. Pore water profiles of $\mathrm{NO}_{3}{ }^{-}, \mathrm{NO}_{2}{ }^{-}, \mathrm{Fe}^{2+}, \mathrm{Mn}, \mathrm{H}_{2} \mathrm{~S}$ and $\mathrm{NH}_{4}{ }^{+}$at all sediment core stations. The uppermost data points in each profile represent bottom water values. Note differing concentration scales at different sites. The data shown in this figure are contained in the Electronic Annex.

Figure 4. Plots of $\mathrm{Mn} / \mathrm{Al}$ (note logarithmic axis), $\mathrm{Fe}_{\mathrm{T}} / \mathrm{Al}, \mathrm{Fe}_{\mathrm{HR}} / \mathrm{Fe}_{\mathrm{T}}, \mathrm{Ti} / \mathrm{Al}$ (all element ratios in $\mathrm{mg} / \mathrm{mg}$ ) and $\delta^{56} \mathrm{Fe}$ versus water depth for all sediment core stations. Strongly deviating values of $\mathrm{Fe}_{\mathrm{T}} / \mathrm{Al}$ and $\delta^{56} \mathrm{Fe}$ at the vent field site are shown with a separate $\mathrm{y}$-axis. Horizontal dashed lines depict the upper continental crust (element ratios) (McLennan, 2001), modern continental margin sediment with oxic bottom water $\left(\mathrm{Fe}_{\mathrm{HR}} / \mathrm{Fe}_{\mathrm{T}}=0.28\right)$ (Raiswell and Canfield, 1998) and average igneous rocks $\left(\delta^{56} \mathrm{Fe}=\right.$ $+0.09 \%$ ) (Beard et al., 2003). The data shown in this figure are contained in the Electronic Annex.

Figure 5. Plot of $\mathrm{Fe}_{\mathrm{HR}} / \mathrm{Fe}_{\mathrm{T}}$ versus $\mathrm{Fe}_{\mathrm{T}} / \mathrm{Al}$ featuring a trend line corresponding to the delivery of nonlithogenic reactive $\mathrm{Fe}$. Sediments that receive excess reactive $\mathrm{Fe}$ through lateral transport of dissolved or particulate Fe originating from reducing sediments or from hydrothermal sources are expected to plot on this trend line (Scholz, 2018). The open star (terrigenous input) depicts the $\mathrm{Fe}_{\mathrm{HR}} / \mathrm{Fe}_{\mathrm{T}}$ of continental margin sediments with oxic bottom water (Raiswell and Canfield, 1998) and the $\mathrm{Fe}_{\mathrm{T}} / \mathrm{Al}$ of the upper continental crust (McLennan, 2001). The range of $\mathrm{Fe}_{\mathrm{HR}} / \mathrm{Fe}_{\mathrm{T}}$ and $\mathrm{Fe}_{\mathrm{T}} / \mathrm{Al}$ reported for sediment from the euxinic Black Sea is shown for comparison (Raiswell and Canfield, 1998; Lyons and Severmann, 2006) (note, $\mathrm{Fe}_{\mathrm{HR}} / \mathrm{Fe}_{\mathrm{T}}$ and $\mathrm{Fe}_{\mathrm{T}} / \mathrm{Al}$ were not determined on the same samples).

Figure 6. Deep water current directions ( $0^{\circ}$ equals north) and velocities (color) southeast of the vent site during the 40-hour deployment of the ADCP lander. The distance from the center equals the 
834 time, during which currents were directed into a given direction in percent of the total deployment 835 time. The fraction of a given range of current velocities during the total deployment time is given in percent in parentheses in the legend. The location and distance of the basin and graben sites relative to the ADCP lander (vent field site) are shown as well.

838 Figure 7. Plot of $\mathrm{Fe}_{\mathrm{T}} / \mathrm{Al}$ versus $\delta^{56} \mathrm{Fe}$ for sediments from: (A) the Black Sea (Severmann et al., 2008) 839 and Peruvian continental margin (Scholz et al., 2014b) and (B) the Gulf of California (this study). 840 Uncertainties on published data are not shown for clarity. The regression slopes of Black Sea and 841 Peru margin (OMZ, below OMZ) data are shown in (B) using the average $\mathrm{Fe}_{\mathrm{T}} / \mathrm{Al}$ and $\delta^{56} \mathrm{Fe}$ at the shelf 842 site as the intercept. Note differing axes scales in (A) and (B). The black box in (A) depicts the range of 843 data shown in (B).

844 Figure 8. Plot of $\delta^{56} \mathrm{Fe}$ versus $\mathrm{Al} / \mathrm{Fe}_{\mathrm{T}}$. The black line depicts a mixing trend between sediments at the 845 shelf $(0 \%)$ and vent field $(100 \%)$ sites. The gray array depict the range of $\delta^{56} \mathrm{Fe}$ observed in a 846 dissolved Fe plume emanating from the Peruvian margin into the open Pacific (John et al., 2018).

847 Figure 9. Plot of $\mathrm{Fe}_{\mathrm{py}} / \mathrm{Fe}_{\mathrm{HR}}$ (extent to which highly reactive $\mathrm{Fe}$ has been converted to pyrite) versus $848 \mathrm{Fe}_{\mathrm{HR}} / \mathrm{Fe}_{\mathrm{T}}$ featuring fields that are used to identify oxic, ferruginous and euxinic depositional 849 environments in the paleo-record (Raiswell and Canfield, 2012). Gray arrays represent transitional 850 ranges, where data could be consistent with either redox state. The data shown in this figure are 851 contained in the Electronic Annex. 


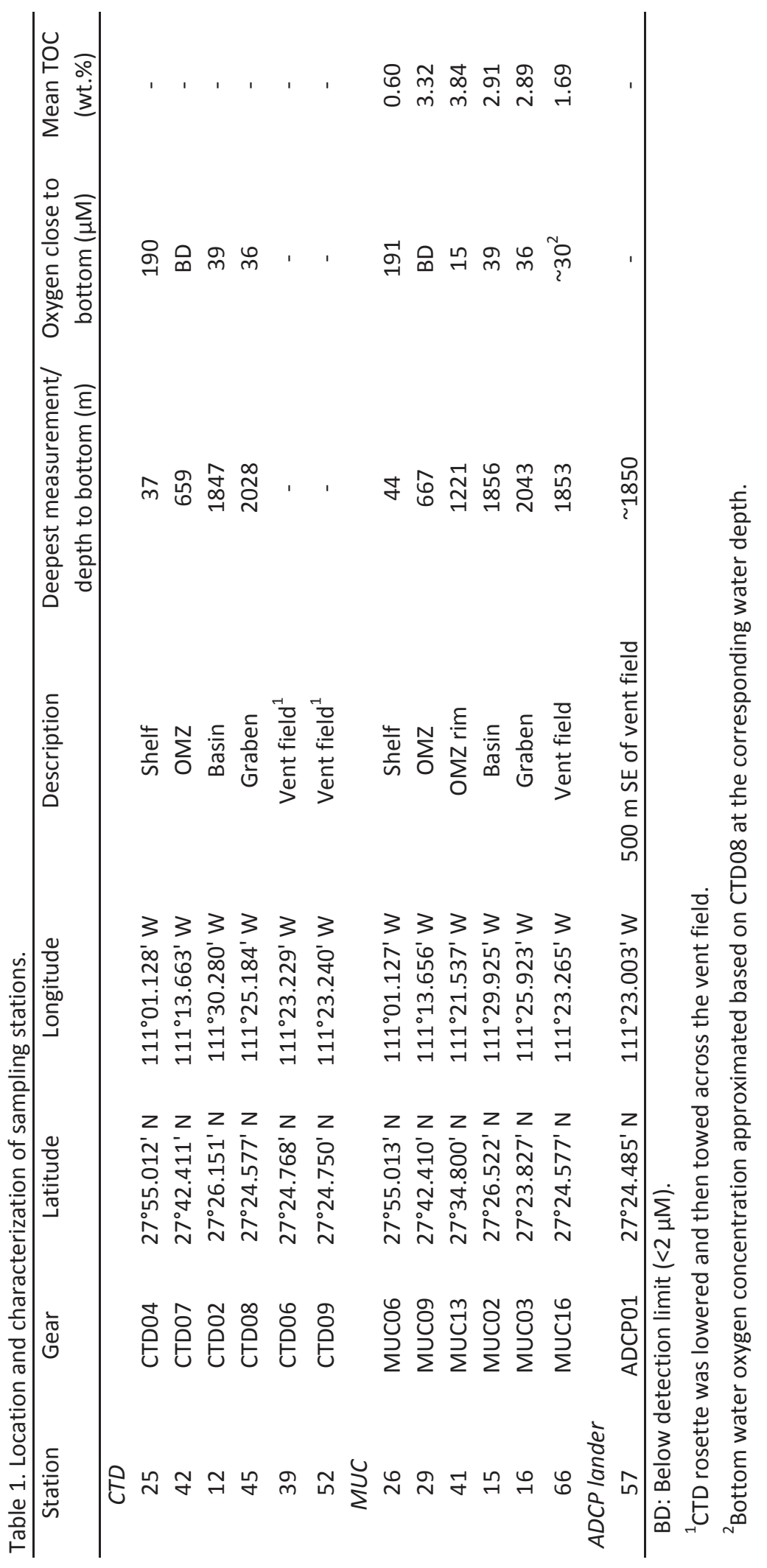




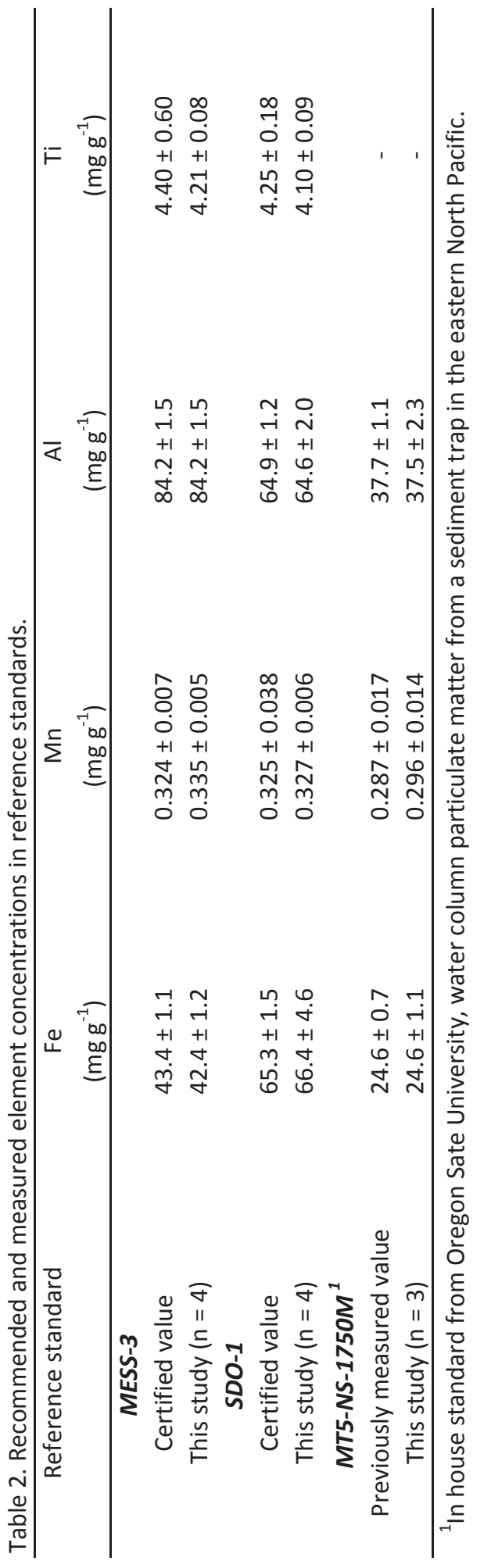




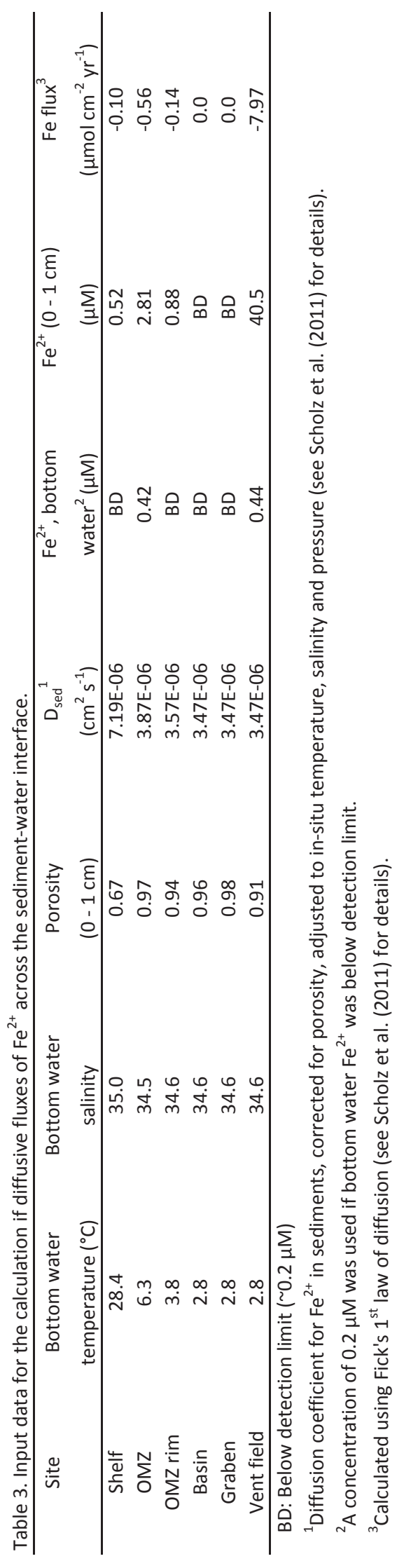




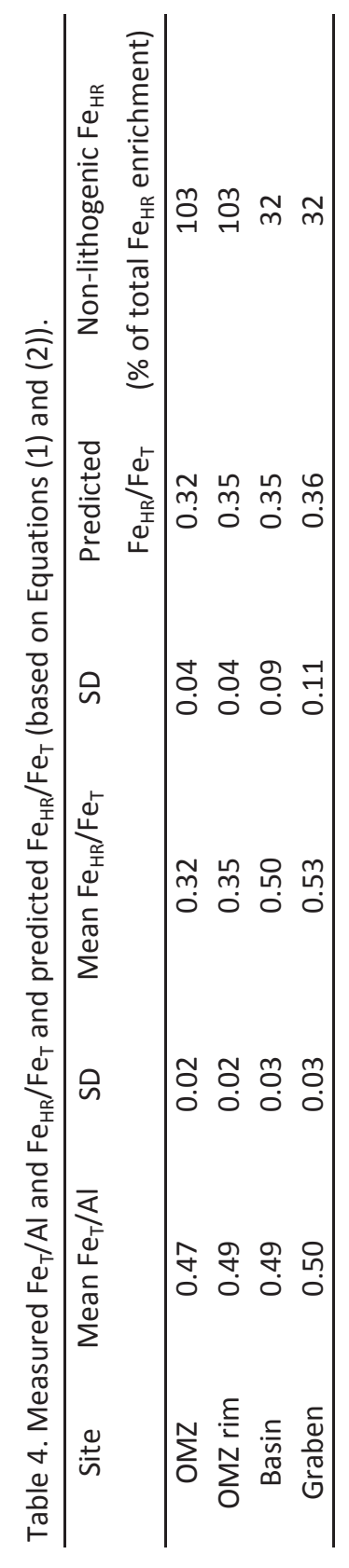



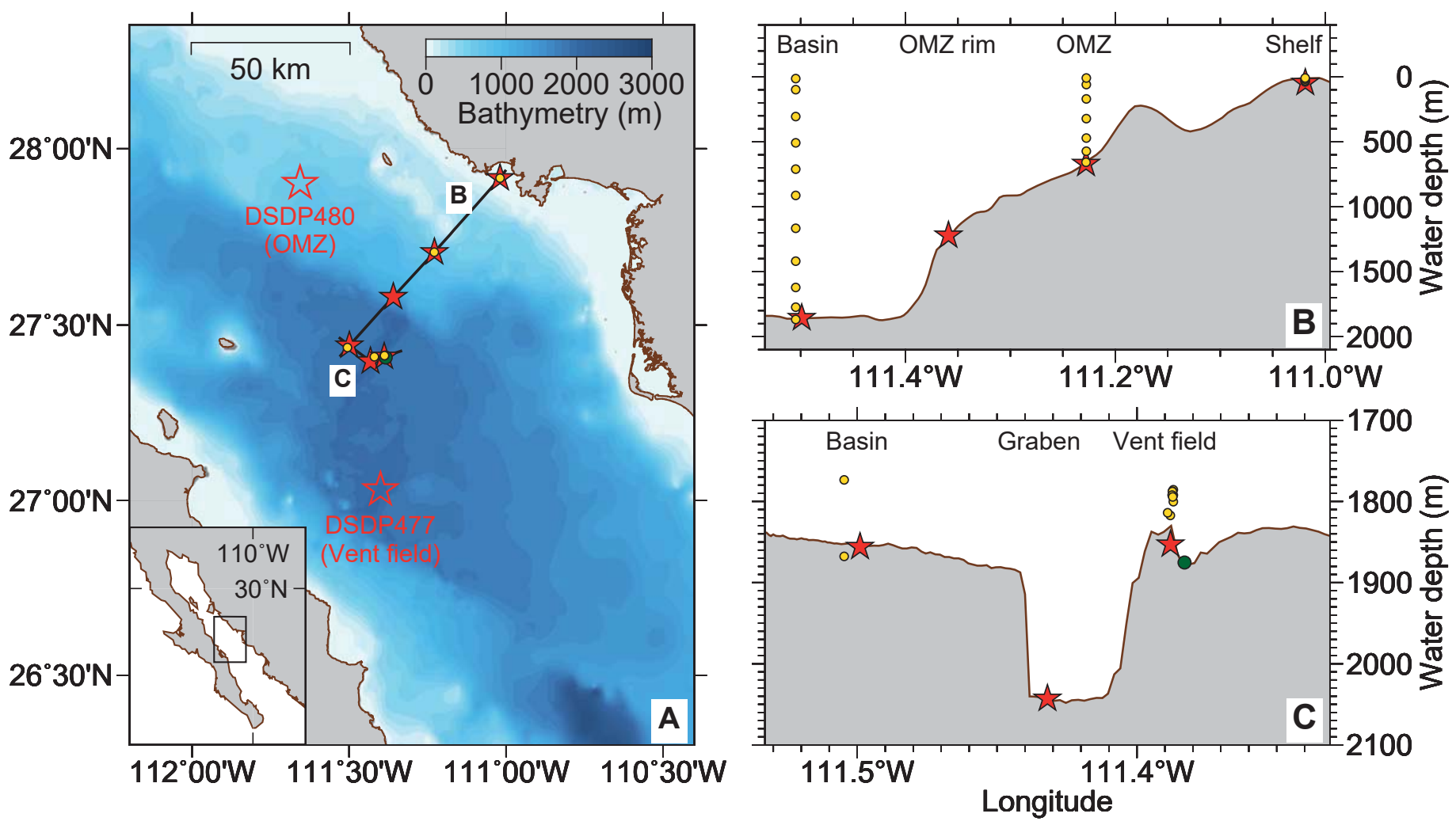

Figure 1 

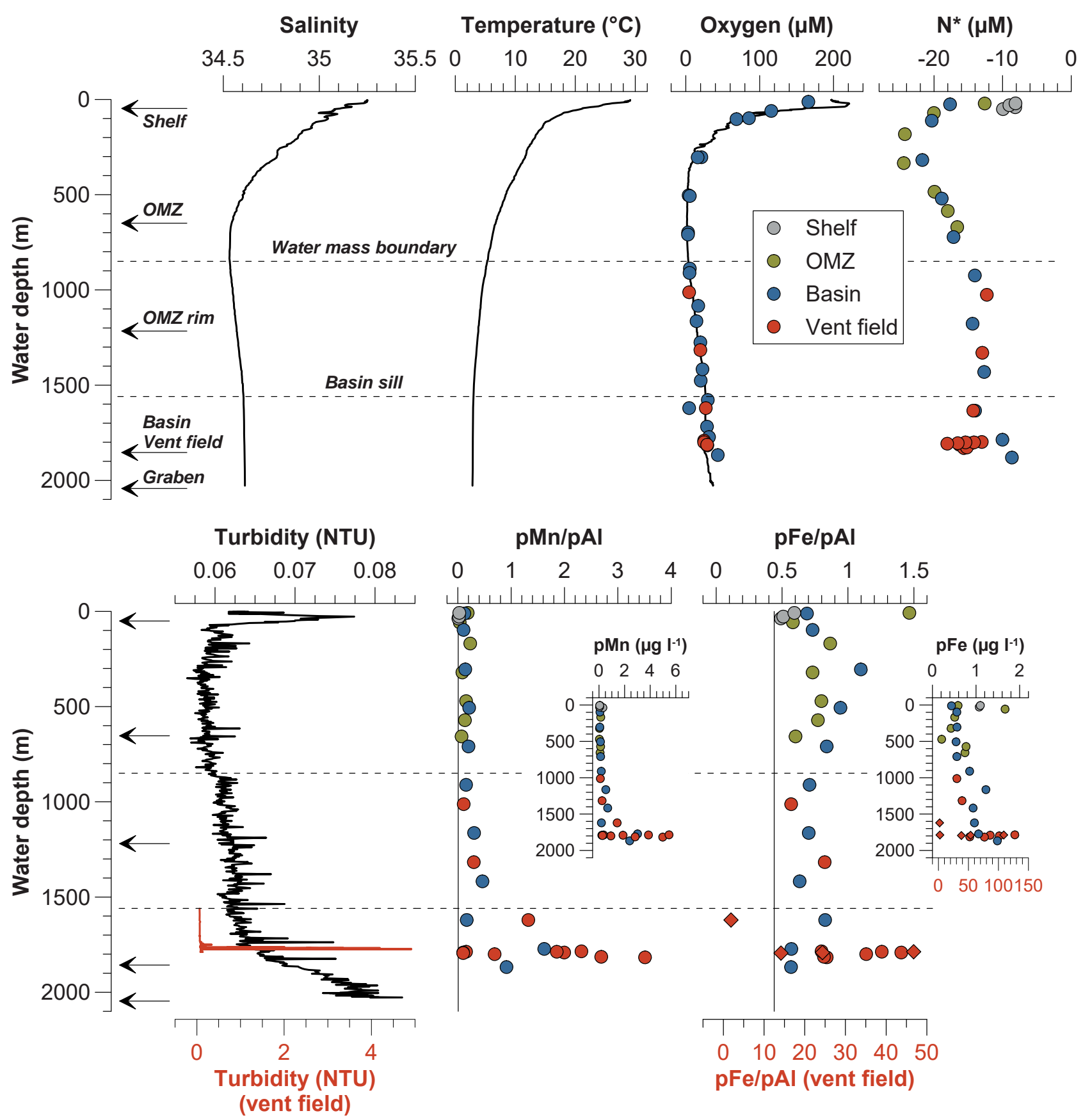

Figure 2 

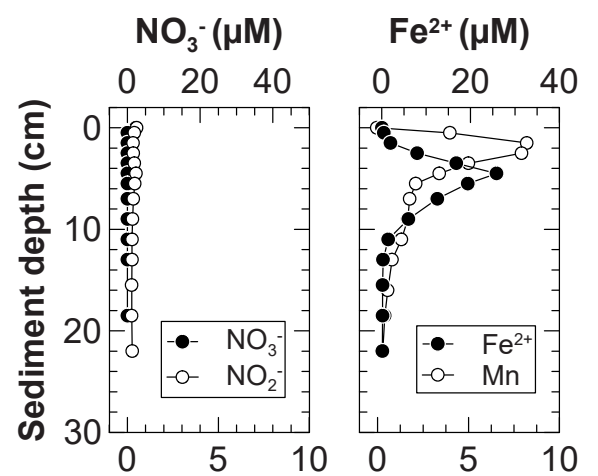

$\mathrm{H}_{2} \mathbf{S}(\mu \mathrm{M})$
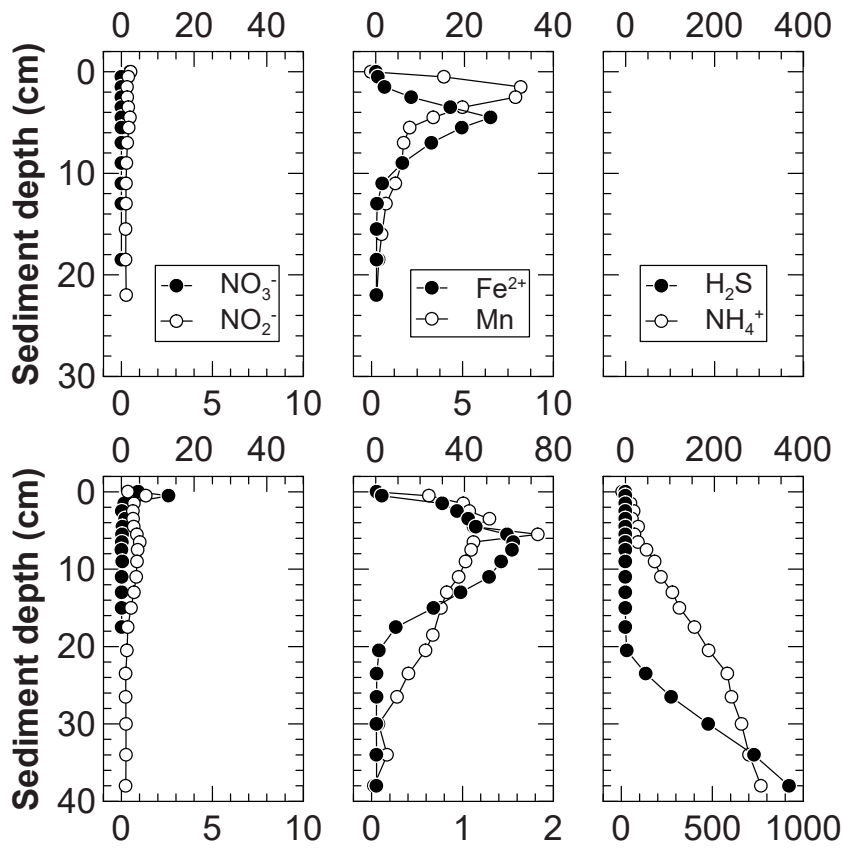
26-MUC06
$44 \mathrm{~m}$ water depth Shelf

29-MUC09

$667 \mathrm{~m}$ water depth $O M Z$
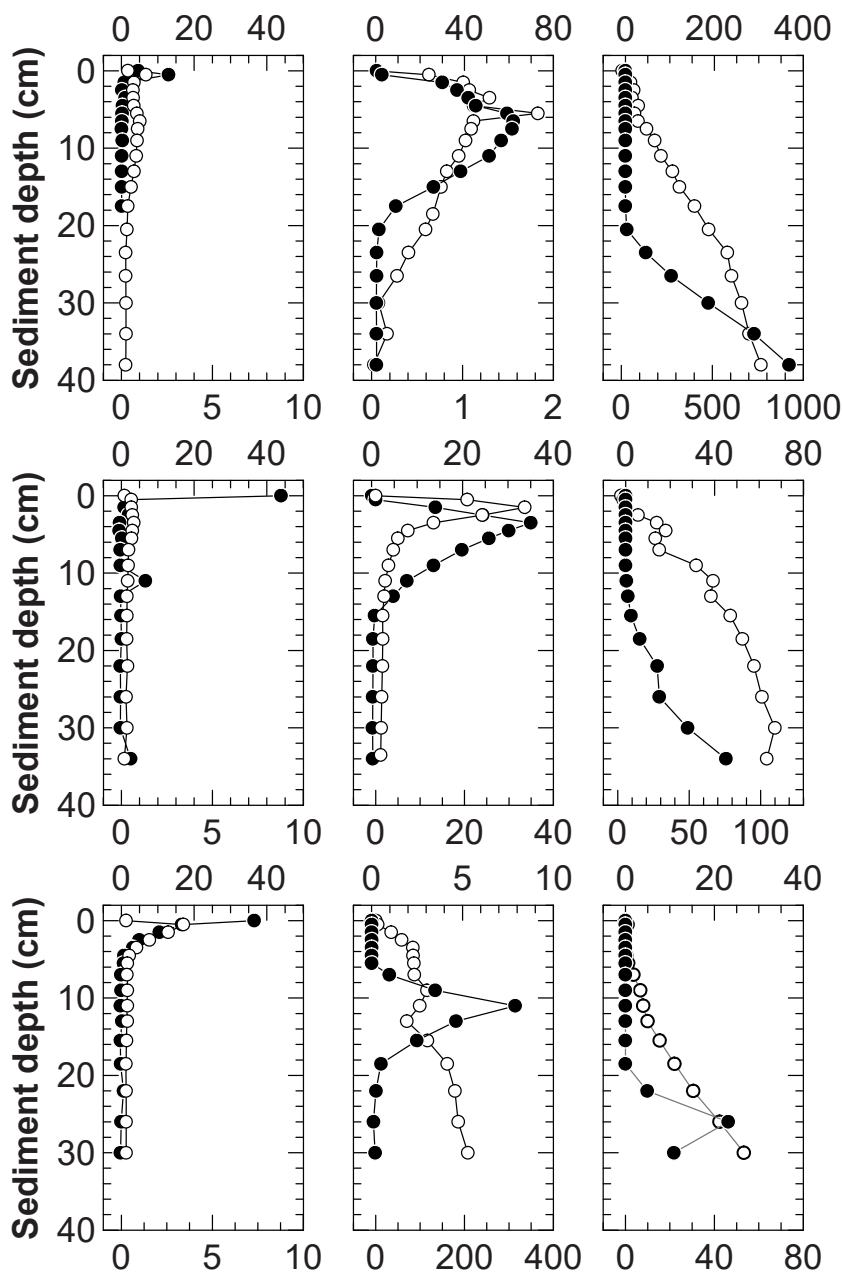

41-MUC13

$1221 \mathrm{~m}$ water depth OMZ rim
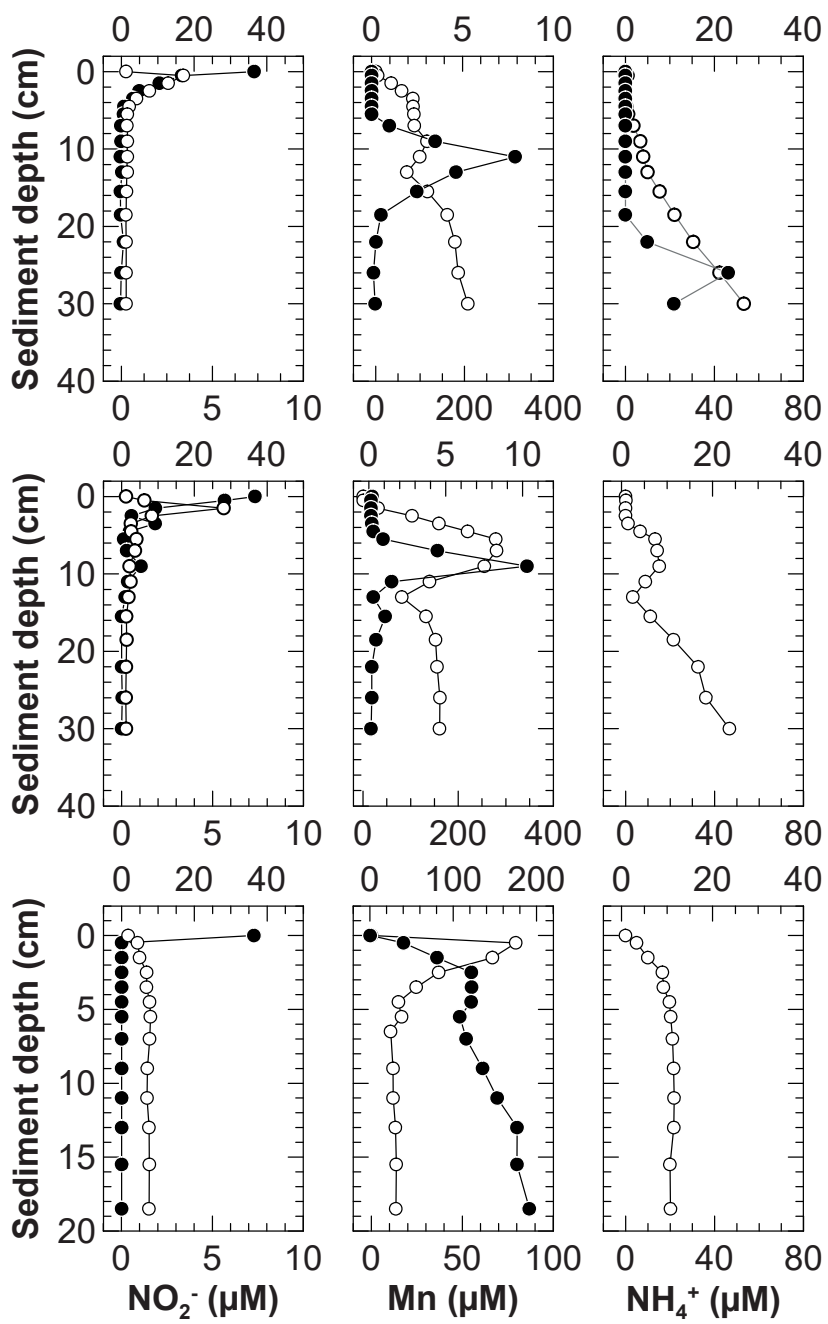

\section{5-MUCO2 \\ $1856 \mathrm{~m}$ water depth Basin}

16-MUCO3

$2043 \mathrm{~m}$ water depth Graben

66-MUC16

$1853 \mathrm{~m}$ water depth Vent field

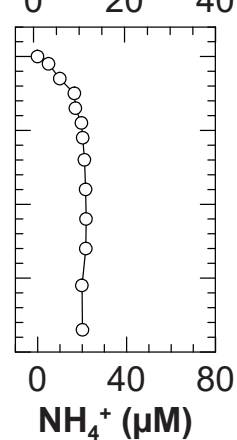

Figure3 


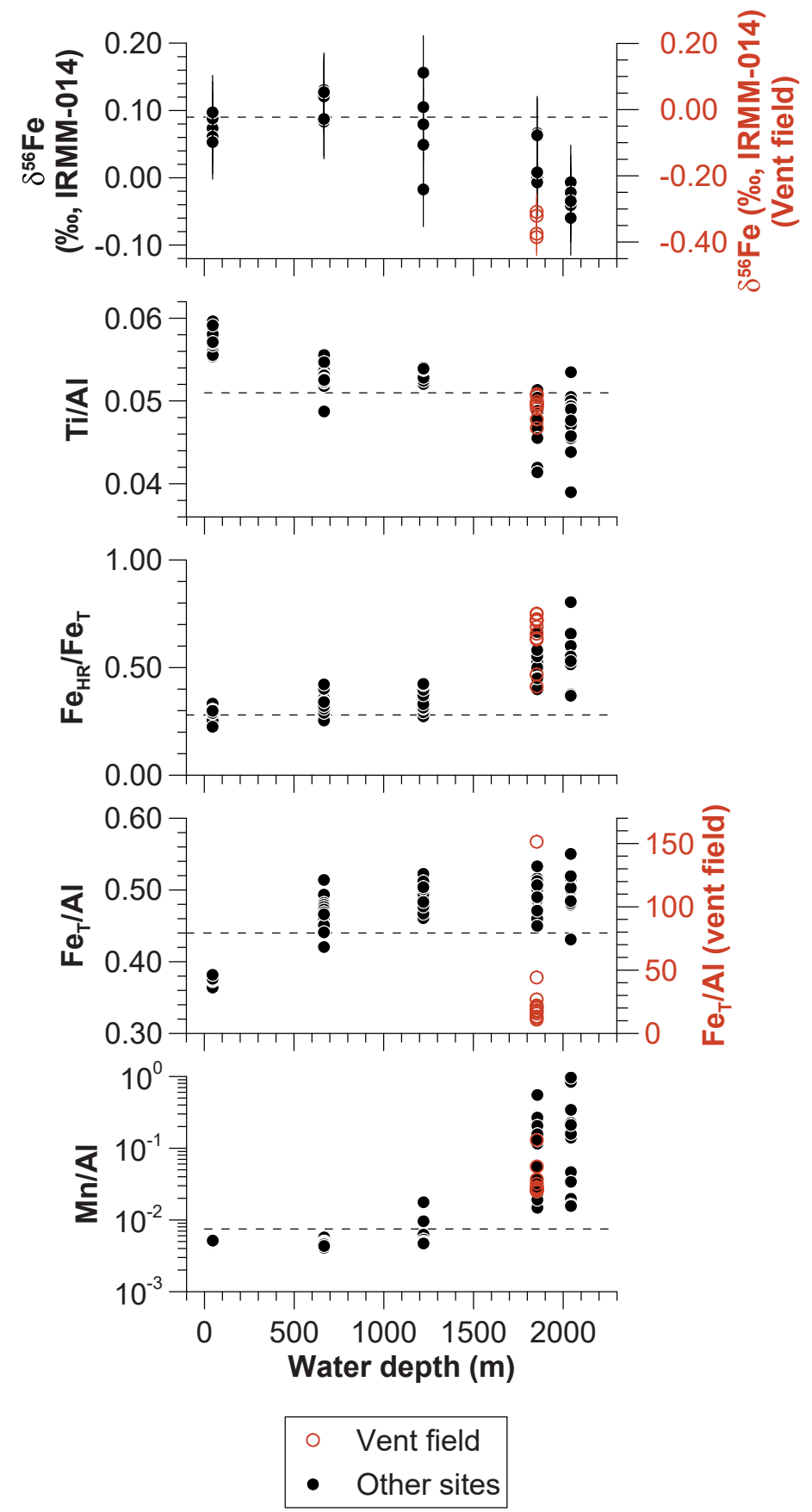

Figure 4 


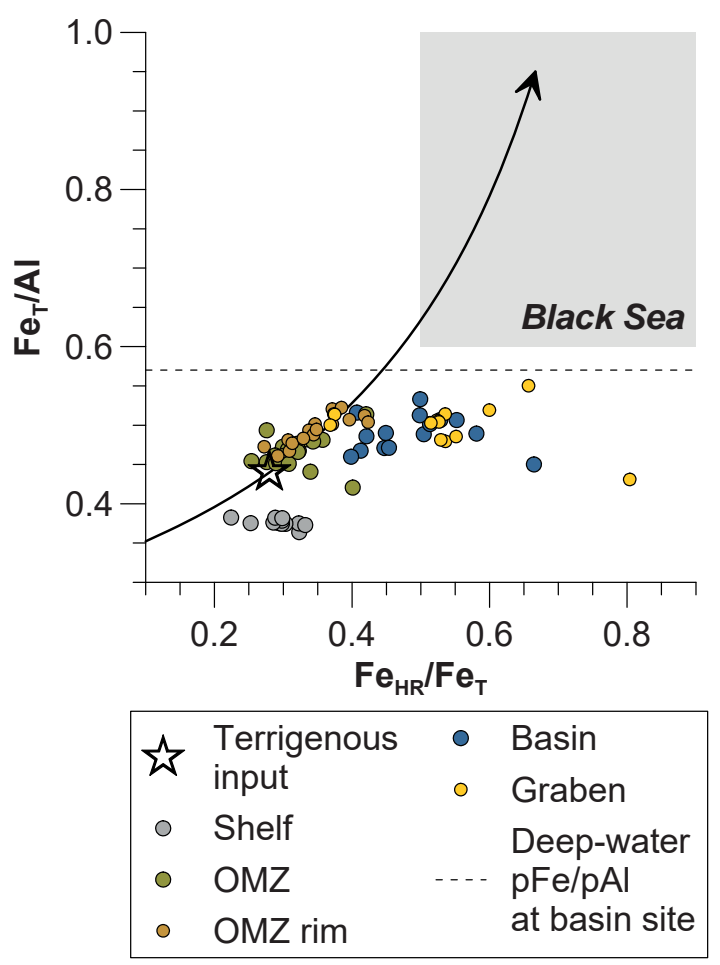

Figure 5 


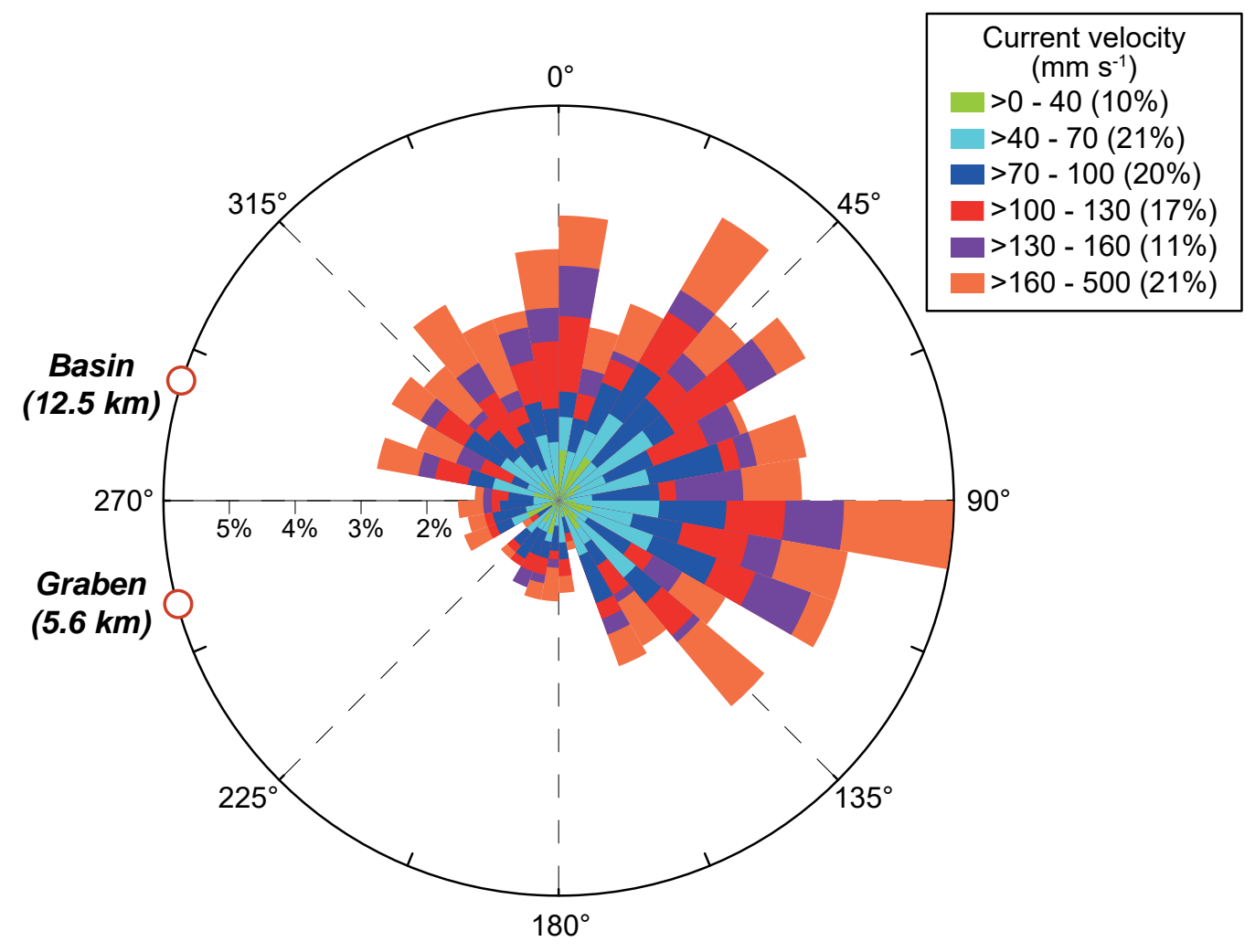

Figure 6 

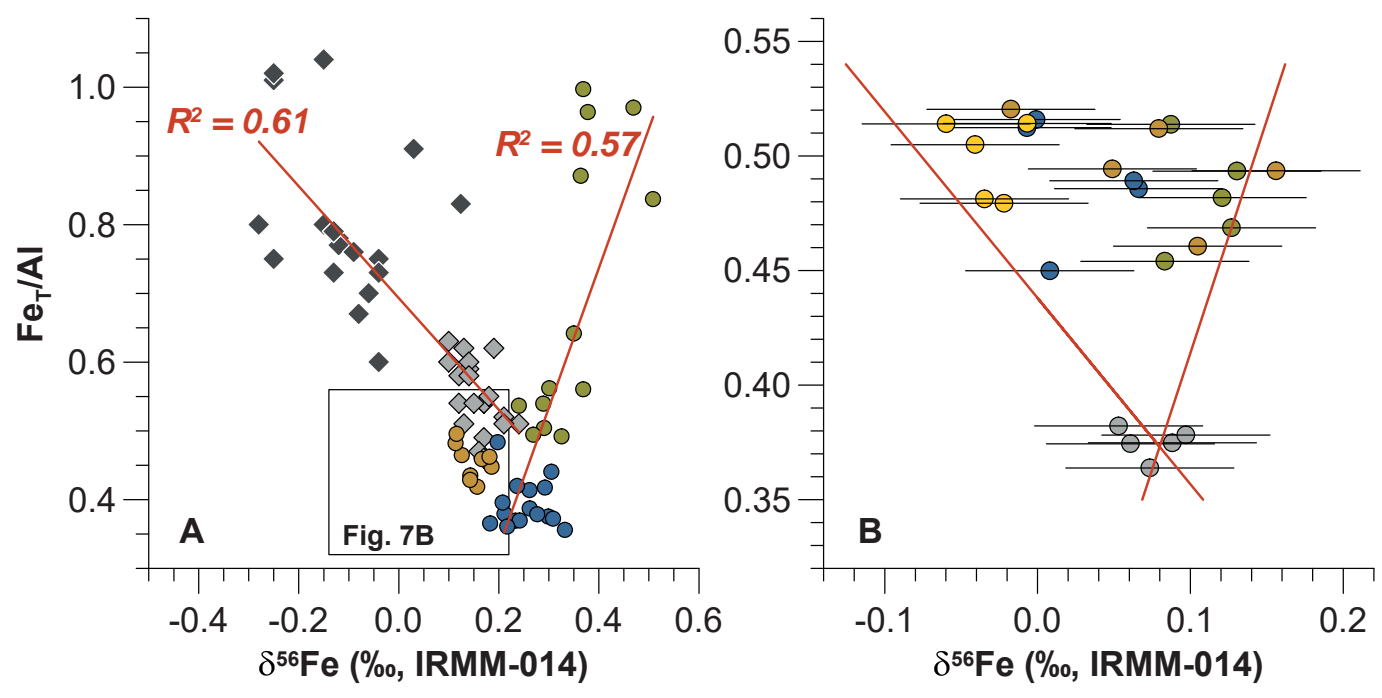

$\diamond \quad$ Black Sea, shelf

- Black Sea, euxinic basin

- Peru margin, shelf

- Peru margin, OMZ

- Peru margin, below OMZ

\begin{tabular}{|clcl|}
\hline \multicolumn{4}{|c|}{ Guaymas Basin } \\
$\circ$ & Shelf & $\bigcirc$ & Basin \\
$\circ$ & OMZ & $\bigcirc$ & Graben \\
$\circ$ & OMZ rim & & \\
\hline
\end{tabular}

Figure 7 


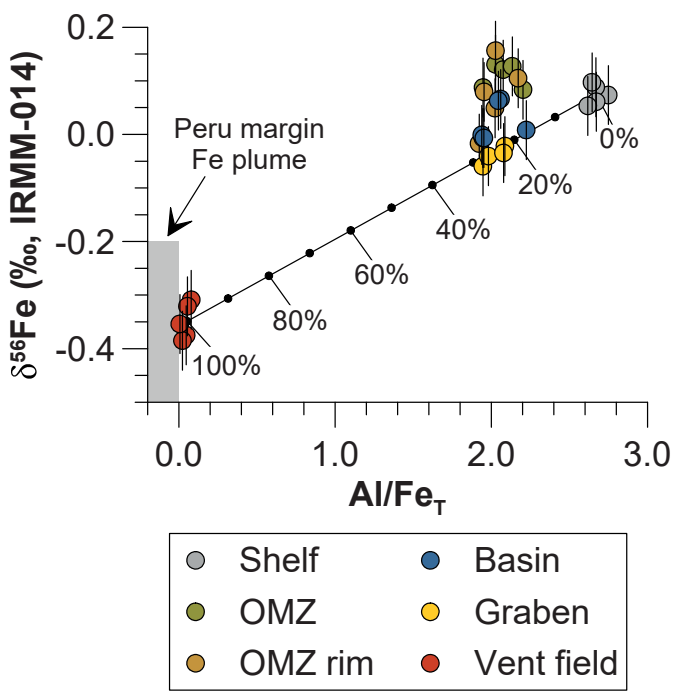

Figure 8 


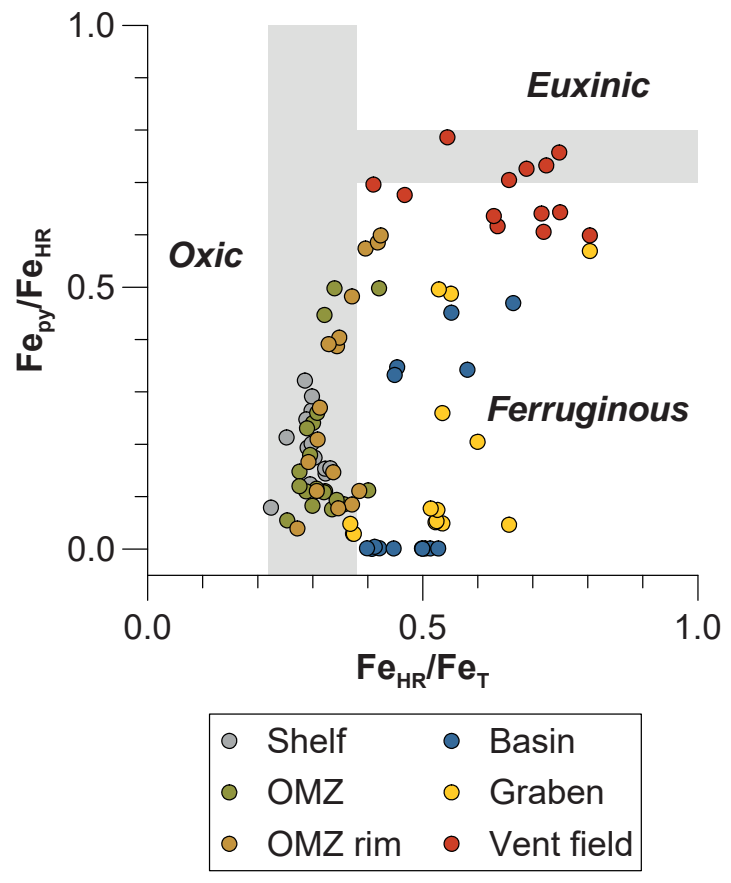

Figure 9 